\title{
How Banks Price Loans for LBOs: An Empirical Analysis of Spread Determinants *
}

\author{
Paulo P. Alves \\ Universidade Católica Portuguesa, Católica Porto Business School and CEGE, Porto, Portugal \\ and \\ International Centre for Research in Accounting, Lancaster University Management School \\ palves@porto.ucp.pt \\ M. Ricardo Cunha \\ Universidade Católica Portuguesa, Católica Porto Business School, Porto, Portugal \\ rcunha@ porto.ucp.pt \\ Luís K. Pacheco \\ Universidade Católica Portuguesa, Católica Porto Business School, Porto, Portugal \\ lpacheco@porto.ucp.pt \\ João M. Pinto \\ Universidade Católica Portuguesa, Católica Porto Business School and CEGE, Porto, Portugal \\ jpinto@porto.ucp.pt
}

March 29, 2021

\begin{abstract}
This paper examines which factors determine the pricing of loans for LBOs, using a worldwide sample of 11,111 loans closed in the 2000-2016 period. Our findings are consistent with the hypotheses that loans for LBOs extended to borrowers in market- versus bank-based financial systems are differently priced, and that law and institutional characteristics are important determinants of spreads for deals closed in market-oriented countries. Despite LBO loan pricing differing significantly in normal versus crisis times, loans extended to borrowers in market-based financial systems have higher spreads than those where banks play a major role. Our results also support the hypothesis of tranching as a mechanism of reducing spreads by completing financial markets and mitigating informational asymmetries. Finally, a robust convex relationship between spread and maturity is found, suggesting higher market competition by banks and investors for standard, medium-term maturities.
\end{abstract}

Please address all correspondence to:

João M. Pinto

Católica Porto Business School

Rua Diogo Botelho, 1327

4169-005 PORTO

e-mail: jpinto@ porto.ucp.pt

* The authors thank Miguel Ferreira, Antonios Kalyvas, Ambrus Kecskes, William Megginson, Álvaro Nascimento, Ricardo Ribeiro, Esperança Tchili, Haluk Ünal, and an anonymous referee for their helpful suggestions. We would also like to thank participants in the FMA 2017 Annual European Conference in Lisbon, the 2017 INFINITI Conference on International Finance in Valencia, and the 7th Accounting and Finance Conference of the Catholic University of Portugal-Porto for helpful comments on earlier drafts. Financial support from Fundação para a Ciência e Tecnologia (through project UID/GES/00731/2019) is gratefully acknowledged. 


\title{
How Banks Price Loans for LBOs: An Empirical Analysis of Spread Determinants
}

\begin{abstract}
This paper examines which factors determine the pricing of loans for LBOs, using a worldwide sample of 11,111 loans closed in the 2000-2016 period. Our findings are consistent with the hypotheses that loans for LBOs extended to borrowers in market- versus bank-based financial systems are differently priced, and that law and institutional characteristics are important determinants of spreads for deals closed in market-oriented countries. Despite LBO loan pricing differing significantly in normal versus crisis times, loans extended to borrowers in market-based financial systems have higher spreads than those where banks play a major role. Our results also support the hypothesis of tranching as a mechanism of reducing spreads by completing financial markets and mitigating informational asymmetries. Finally, a robust convex relationship between spread and maturity is found, suggesting higher market competition by banks and investors for standard, medium-term maturities.
\end{abstract}

Key words: loan pricing, LBOs, financial crisis, market-based, term structure of spreads.

JEL classification: F34; G01; G21; G34

March 29, 2021 


\section{Introduction}

A Leveraged Buy-Out (LBO) is usually presented as the acquisition of a corporation or division by a group of investors using a high percentage of debt financing, while borrowing against the target's future cash flows. ${ }^{1}$ The acquisition takes place off-balance-sheet for the proponents and the bulk of the capital needed for the operation is provided by financial intermediaries through debt, which typically comprises $60 \%$ to $70 \%$ of the financing structure. There are usually three reasons indicated as to why LBO firms rely heavily on bank debt, primarily through syndicated loans (Kaplan and Stein 1993; Demiroglu and James 2010). ${ }^{2}$ First, concentrated ownership makes bank loans easier to negotiate (Berlin and Loeys 1988; Chemmanur and Fulghieri 1994). Second, banks are thought to have a comparative advantage in monitoring such loans (Fama 1985; Boyd and Prescott 1986). Finally, more short-term bank debt increases the incentive effects of debt (Jensen 1986).

According to the World Economic Forum Private Equity Report (2008), LBO activity has increased greatly over the years and in the mid-2000s a second LBO boom was observed, with a record amount of capital committed to private equity. While the total value of firms acquired through LBOs between 1970 and 2007 has been estimated at $\$ 3.6$ trillion, \$2.7 trillion of these transactions took place between 2001 and 2007. Despite the financial turmoil in the debt markets after 2008, the total value of firms acquired through LBOs between 2008 and 2016 was more than \$1.5 trillion (Singh 2017). Thus, LBOs are an economically significant financial market segment. However, research on LBOs is relatively scarce and little is known about these operations, particularly their financing structures and the pricing of loans arranged for LBOs. ${ }^{3}$

In this paper, we intend to contribute to the extant literature by examining what the main drivers of LBO loan pricing are. The main objective is that of exploring the different pricing mechanisms in marketversus bank-based financial systems, and in pre-versus crisis years, with a particular focus on the role of

\footnotetext{
${ }^{1}$ For further discussion see, e.g., Kaplan and Stein (1993), Nikoskelainen and Wright (2007), Kaplan and Strömberg (2009), and references therein.

${ }^{2}$ According to Esty and Megginson (2003), syndicated loans are pyramids with a few arranging banks (arrangers) at the top and many providing banks (providers) at the bottom.

${ }^{3}$ Extant literature is concentrated particularly upon the determinants of an LBO and also on estimating the value for the shareholders of such an acquisition (Caselli and Gatti 2005).
} 
loans' tranching and time to maturity in determining LBO loan spreads. For this purpose, we use a worldwide sample of 3,877 deals - 11,111 individual loan tranches worth $\$ 1,626.1$ billion - closed between 2000 and 2016, representing $39.7 \%$ of total LBO volume by deal size in our sampling period.

The academic literature contains numerous loan pricing studies, namely on the pricing of corporate loans and bonds. ${ }^{4}$ Despite a larger number of studies on the pricing of project finance loan spreads, research on other types of syndicated loans has been scant. ${ }^{5}$ As to our knowledge, there are only two empirical papers studying the determinants of syndicated loan spreads in LBOs. Ivashina and Kovner (2011) study the impact of U.S. private equity firms' bank relationships on the terms of their syndicated loans, and find that an increase in bank relationship strength is associated with more favorable borrowing terms: lower spreads and higher maximum debt to EBITDA covenant. Authors also provide evidence of contractual - deal size and maturity - and targeting firms' characteristics - capturing their creditworthiness -, affecting loan spreads. Colla et al. (2012) study the determinants of both capital structure and debt pricing, and find that spreads mostly depend on the target firm's pre-LBO profitability. In addition, they find that spreads are directly related to variables such as market conditions captured by equity volatility and market-wide cost of debt, contractual characteristics, like maturity and covenant intensity, and loan types/seniority. Concerning the micro factors influencing LBO pricing, we extend Ivashina and Kovner's (2011) and Colla et al.'s (2012) findings by investigating the impact of LBO debt tranching effect on loan spreads. ${ }^{6}$ The complex structure of multiple debt tranches in LBOs provides a sound laboratory to examine the relationship between tranching and syndicated loans' pricing. We argue that structuring LBO debt into tranches with different seniority levels reduces market incompleteness and asymmetric information, allowing borrowing costs to be reduced (Maskara 2010; Cumming et al. 2020). In relation to the macro-

\footnotetext{
${ }^{4}$ See Collin-Dufresne et al. (2001), Campbell and Taksler (2003), Titman et al. (2004), Longstaff et al. (2005), Chen et al. (2007), Qian and Strahan (2007); Bae and Goyal (2009); Maskara (2010); Bharath et al. (2011); and Flannery et al. (2012), for examples of this literature.

${ }^{5}$ Kleimeier and Megginson (2000) classify syndicated loans in five categories: project finance loans; corporate control loans (e.g., leveraged buy-outs); capital structure loans; fixed asset-based loans; and general corporate purpose loans. ${ }^{6}$ Syndicated loans can be tranched into heterogeneous loans, usually distributed across lenders with different risk aversion (Maskara 2010).
} 
level factors, we believe our study is the first to investigate whether the pricing mechanism and main loan spread determinants vary in market- vis-à-vis bank-based financial systems and in the pre-versus crisis periods.

Results obtained from a generalized method-of-moments (GMM) estimation method show that LBO loans extended to borrowers in market- versus bank-based financial systems as well as in the pre- versus crisis periods are differently priced. We find that the 2008 financial crisis and the subsequent European sovereign debt crisis have imposed a significant increase in spreads for loans in LBOs. Our results show that loan tranching affects spreads significantly. In line with security design (Duffie and Rahi 1995; Riddiough 1997) and contractual finance (Maskara 2010; Cumming et al. 2020) literature, we find that the design of different tranches with different risk-return profiles reduces loan spreads. LBO loan spreads are also explained by contractual characteristics (maturity, deal size, subordination, and currency risk), the bank syndicate structure (bank relationship, number of lenders and lead bank reputation), and macroeconomic factors (market volatility and the yield curve slope). We also corroborate Colla et al.'s (2012) findings by showing that targeting firms' pre-LBO profitability is a primary determinant of spreads. Loan pricing results are robust when performing a deal-level analysis and control for targeting firms' characteristics. ${ }^{7}$

The paper complements other research on the relative merits of bank-versus market-based financial systems. One strand of the literature argues that the financial system structure matters: a country's financial system affects its economic development (Demirgüç-Kunt and Levine 1999; Chakraborty and Ray 2006; Ergungor 2008). On the other hand, the law and finance view argues that a country's legal system is a primary determinant of the effectiveness of its financial system (La Porta et al. 2000; Beck and Levine 2002; Levine 2002), with common-law countries being associated with stronger creditor and shareholder protection and more developed financial markets. Consistent with this approach, Beck and Levine (2002) and Demirgüç-Kunt and Maksimovic (2002) find no evidence that variations in the development of the financial system unrelated to the legal system are closely associated with economic growth. In addition,

\footnotetext{
${ }^{7}$ We examine the impact of targeting firms' characteristics on the pricing of LBO loans by using a unique dataset of loans and firms' characteristics carefully hand matched from DealScan and Datastream.
} 
extant literature on syndicated loan pricing shows that stronger creditor protection and debt enforcement reduce loan spreads (Qian and Strahan 2007; Bae and Goyal 2009). However, none of these studies examines whether the type of financial system affects pricing and the cost of borrowing. The LBO context is particularly interesting for such a study: LBO transactions create new private organizations that are financed through a combination of equity from private equity investors and debt from a relatively large number of creditors (Cao et al. 2016). We add to previous literature by providing a better understanding of how financial systems and their law and institutional characteristics - shareholder rights, creditor rights, and enforceability of contracts - affect LBO loan pricing.

We show that the financial system structure is important in explaining LBO loan spreads. Our findings document that, after controlling for investor rights and enforceability of contracts, as well as micro - at the contract, syndicated structure, and target-firm level - and other macro factors, spreads for loans extended to borrowers in market-based financial systems have higher spreads than those in bank-based financial systems. We thus find that the LBO loan syndicated market is not globally integrated. We also find that law and institutional characteristics affect loan spreads especially for those extended to borrowers in market-oriented countries: both creditor rights and enforceability proxies reduce credit spreads. On the contrary, the development level of a country's contracting environment does not influence loan spreads in the bank-based sub-sample. The only exception is verified for the enforcement level in the crisis period, which positively affects spreads in bank-oriented countries. Our results are thus consistent with the relevance of both financial system structure and the legal system, mainly creditor's protection and enforceability of contracts, on borrowers' cost of loan finance. Results are robust in pre-versus crisis period.

This paper also contributes to a recent body of literature on the term structure of spreads, which is particularly puzzling for syndicated loans. Kleimeier and Megginson (2000) conclude that project finance loan pricing is not a positive function of maturity. Sorge and Gadanecz (2008) study this apparent absence of a clear relationship between spreads and maturity and show that the term structure of spreads is 'humpshaped'. Likewise, Marques and Pinto (2020) find non-linear relationships between credit spreads and the maturity of structured finance bonds. Regarding non-project finance syndicated loans, several authors (e.g., 
Scott and Smith 1986; Bae and Goyal 2009; Lin et al. 2011; Ivashina and Kovner 2011; Colla et al. 2012) argue that, on average, the term structure of spreads appears upward-sloping. We extend Ivashina and Kovner's (2011) and Colla et al.'s (2012) work by modelling the term structure of spreads for LBO loans controlling for several micro- (at the contract and target-firm) and macro-level factors.

Our findings are consistent with the hypothesis that the term structure of spreads in LBO loans differs from that of corporate financing loans. We find a convex relationship between spread and maturity, which is more pronounced for loans extended to borrowers in bank-based financial systems than in market-based financial systems. We find robust results when using interaction terms with the dummy for the financial crisis and when collapsing tranches at the deal level and examine the cost of LBO debt through a weighted average spread. This "smile" effect can be explained by the intrinsic characteristics of LBO transactions liquidity risk and leverage level - and by loan market effects - higher market competition by banks and investors for standard, medium-term maturities.

This paper is organized as follows. Section 2 reviews the literature and describes the research hypotheses. Section 3 describes the methodology, data and variables we use in our tests. In section 4, we examine the determinants of LBO loan spreads. Section 5 provides robustness checks and extensions, controlling for targeting firms' characteristics, using alternative variables as well as tests for potential sample selection effect. Section 6 presents the main conclusions of this study.

\section{Background information and hypotheses}

\subsection{The financial economics of $L B O s$}

LBOs are one type of leveraged acquisitions. Kaplan and Strömberg (2009) refer that in an LBO ‘a company is acquired by a specialized investment firm using a relatively small portion of equity and a relatively large portion of outside debt financing.' Several authors point out that LBOs create economic value by $(i)$ reducing agency problems, (ii) increasing operating performance, and (iii) increasing interest

tax shields (Kaplan 1989a,1989b; Lichtenberg and Siegel 1990; Opler and Titman 1993; Kaplan and Strömberg 2009). Other sources of wealth gains are also presented as motivations, namely wealth transfers, corporate undervaluation, reduction of transaction costs, and takeover defenses (Renneboog et al. 2007). 
As a structured finance transaction, an LBO can usefully be conceptualized as a 'nexus of contracts', designed, namely, to curtail asymmetric information problems and mitigate agency conflicts (Caselli and Gatti 2005). ${ }^{8}$ Different from traditional corporate financing, structured financing arrangements provide a framework for extensive and comprehensive contracting, including asset collateralization and restrictive covenants stipulation, which may improve future cash flow predictability and lower asset-inplace riskiness (Leland 2007; Pinto and Santos 2019).

It is possible to find certain unique characteristics in an LBO transaction (Cumming and Zambelli 2010). First, they usually require the incorporation of a special purpose vehicle (SPV) for the transfer of the ownership which, after being capitalized by the proponents, launches the offer for the company to be acquired. Second, the bulk of the capital needed for the operation is supplied by the debt securities provided by banks and financial intermediaries, allowing the exploitation of financial leverage benefits, but introducing a higher intrinsic structural risk when compared to other M\&A transactions (Colla et al. 2012). Third, the debt capital supplied by the banking system is a function of the capacity of the target firm to generate cash flows. The debt portion of the LBO financing structure may include a broad array of syndicated loans, securities, or other debt instruments (Axelson et al. 2009).

Syndicated loans in an LBO are issued with varying seniority and maturity claims, structured to generate differential interests in the deal, such that senior investors have priority rights over subordinated investors. In this line of reasoning, Ivashina and Kovner (2011) point out that debt in an LBO is tranched in numerous levels of seniority - a senior and secured loan portion, purchased by banks and institutional investors and a junior and unsecured portion, financed by high-yield bonds or 'mezzanine debt' -, which reduces monitoring costs and adverse selection problems (Diamond 1993; Winton 1995). Moreover, covenants and additional credit enhancement mechanisms other than subordination, like cash reserve accounts, or a guarantee by third parties, may be assigned to the transaction (Caselli and Gatti 2005; Fabozzi

\footnotetext{
${ }^{8}$ Structured finance is an off-balance-sheet contractual arrangement designed to fund a specified asset, or a segregated pool of assets or cash flow streams, within an SPV incorporated to serve as a separate contracting entity for the transaction parties; e.g., securitization, project finance, LBOs and structured leases (Fabozzi et al. 2006).
} 
et al. 2006). Therefore and contrary to traditional corporate financing loans, spreads in loans for LBOs depend essentially on the contractual structure designed, the credit enhancement mechanisms used, mainly the creation of different tranches with different risk-return profiles, and the target firm's characteristics.

\subsection{Hypotheses}

\subsubsection{Bank-versus market-based financial systems}

At its core, a financial system's major task is to mobilize resources for investment, selecting investment projects to be funded, and providing incentives for the monitoring of investments' performance. A large body of theoretical and empirical research analyzes how these tasks are performed in a marketbased financial system, and how they are performed in a system where banks and other financial intermediaries play a major role. Demirgüç-Kunt and Levine (1999), Chakraborty and Ray (2006) and Ergungor (2008) argue that if a country's financial system is bank or market-oriented affects its economic development and growth. On the contrary, the financial services' perspective argues that it is the ability of the financial system to improve information and reduce transaction costs that matters, not whether banks or markets provide these services; i.e., banks and financial markets might act as complements in providing financial services (Levine 1997).

La Porta et al. $(1997,1998,2000)$ provide a connection between financial system design, laws and regulations, emphasizing the role of a country's legal system as a primary determinant of the financial development level. The law and finance view argues that legal systems that protect investors through effective contract enforcement promote financial development and facilitate external financing, new firm formation and efficient capital allocation. Recent papers on financial structure and economic growth support this view. Demirgüç-Kunt and Maksimovic (2002) find that financial structure is not a robust predictor of economic growth and point out that improvement in access to external finance is obtained via the development of a country's legal system. Beck and Levine (2002) also show that the financial structure per se does not explain industrial performance. They find that industry growth and the efficiency of capital allocation are significantly influenced by financial development and the legal environment. Ergungor (2004) shows that improvement in shareholder and creditor rights promotes stock market and bank development more 
in common-law countries than in civil-law countries. However, Demirgüç-Kunt and Maksimovic (2002) also show that in countries with relatively low levels of financial development, the financial system structure impacts the type of external finance firms obtain. In addition, Ergungor (2008) finds a nonlinear relationship between growth and financial structure, when controlling for the level of financial development.

Furthermore, empirical works on loan pricing show that the corporate loan market is not globally integrated. Carey and Nini (2007) offer evidence that spreads on syndicated loans are, on average, 30 bps smaller in Europe than in the U.S. Qian and Strahan (2007) and Davydenko and Franks (2008) find that spreads are higher in English legal-origin countries than in those with French or Germany legal origin. Concerning LBOs, Colla et al. (2012) find that deal spreads in common-law countries are 32 to 58 bps higher than in civil-law countries. Finally, Cumming et al. (2020) argue that the structure of the financial markets influences loan tranching and pricing.

If we consider the literature on financial system structure, law and finance, and loan pricing together, it is expected that the type of financial system will affect the design of the LBO financing structure, in terms of contractual arrangements and the credit enhancement mechanisms used. Therefore, the impact of pricing variables on LBO loan spreads would be different in market- versus bank-based financial systems. Under this framework, we raise the following hypothesis:

Hypothesis 1 [H1]: LBO loan pricing differs significantly between market-based and bank-based financial systems

Extant literature argues that laws and institutions of different countries affect financial intermediary development, financial contracting and the cost of borrowing (La Porta et al. 1997, 1998; Esty and Megginson 2003; Gatti et al. 2013). Stronger investor protection and enhanced and transparent disclosure rules mitigate asymmetric information and agency costs. As pointed out by Cumming et al. (2020), the rules embedded in bankruptcy and reorganization laws are country-specific and relevant to creditors when deciding to participate in a syndicated loan. Such rules determine the creditors' rights to claim interest and capital payments and secure assets in the event of default (Qian and Strahan 2007). Additionally, legal frameworks that provide better contract enforcement may create the necessary basis for the development 
of larger and more structured financing transactions (La Porta et al. 1998, 2000). The easier it is for lenders to secure their rights, the lower the expected loss is, which impacts spreads and pricing mechanisms (Djankov et al. 2007). This is corroborated by Bae and Goyal (2009), who find that variation in the enforceability of contracts influences significantly how loans are structured and priced.

According to Cao et al. (2019), legal and institutional factors, like shareholder and creditor rights as well as enforcement, are of high importance in LBOs, because they involve much more complicated arm's length contracts and external financing. ${ }^{9}$ Nevertheless, the banking system and securities markets have a comparative advantage in providing different services (Demirgüç-Kunt and Maksimovic 2002). In bank-based financial systems, banks play a fundamental role in firms' financing, providing borrowers with valuable services that individual investors are unable to offer via financial markets. In addition, banks mitigate moral hazard by monitoring borrowers and reduce information asymmetries by establishing close relationships with their customers, reducing banks' cost of making loans and increasing credit availability (Petersen and Rajan 1994; Berger and Udell 1995). When a conflict between a borrower and a lender arises, the bank is still able to enforce the contract without judicial assistance by credibly threatening the borrower of withholding its services by exercising a set of contractual covenants. Motivated by these insights, we conjecture that laws - creditor and shareholder rights - and institutions - efficiency of contract enforcement affect spreads differently in market- versus bank-based financial systems, and are more important in explaining loan spreads in market-oriented countries. This leads to a second hypothesis:

Hypothesis 2 [H2]: Law and institutional characteristics are important determinants of LBO loan spreads, especially when extended to borrowers in market-based financial systems

\subsubsection{Pre-versus crisis periods}

The 2008 financial credit crisis brought collateralized loan obligations (CLOs) to a halt and LBOs have declined significantly - Table A.2 shows that LBO lending increased significantly between 2000 and 2007 (768.6\% by value), fell in 2008 and 2009 and rose again in the 2010-2014 period, becoming stable

\footnotetext{
${ }^{9}$ Cao et al. (2019) provide evidence supporting that institutional context and legal environment impact value creation in LBOs vis-à-vis non-LBO takeovers.
} 
afterwards. As pointed out by Benmelech and Dlugosz (2009) and Kaplan and Strömberg (2009), the influx of capital from CLOs - CDOs backed predominantly by loans - was so significant that the amount of capital committed to private equity in 2006 and 2007 reached record levels, surpassing the first leverage buyout wave of the late 1980s. However, the global financial crisis triggered by the deep plunge in the value of U.S. sub-prime mortgages affected the players in the LBO market. Consequently, borrowers and lenders might have also changed their attitude in terms of pricing and compensation. This is corroborated by Kaplan and Strömberg (2009), providing evidence that market conditions affect significantly LBO valuation ratios, and by Colla et al. (2012), who point out that during hot buyout markets senior lending increases vis-à-vis junior lending and that the first becomes cheaper. We thus hypothesize that:

Hypothesis 3 [H3]: LBO loan pricing differ significantly in normal versus crisis times; i.e., the impact of core variables in loan spreads is significantly affected by the 2008 financial crisis

\subsubsection{Tranching and loan spreads}

DeMarzo (2005) offers market incompleteness and asymmetric information as major explanations for tranching in structured bonds. Tranching makes the market more complete by satisfying the needs of some investors: segmented financial markets may make it attractive for structured finance arrangers to create new assets with desired risk-reward profiles in terms of security design for particular investor classes. Tranching also adds value when heterogeneous investors have different private information and different capabilities to screen investors (DeMarzo and Dufe 1999; DeMarzo 2005). For example, investors facing information asymmetry problems might prefer senior, or less 'information sensitive' tranches, while multiple junior tranches might be designed to exploit investors with private information and specific risk appetites. According to Duffie and Rahi (1995) and Riddiough (1997), market incompleteness and asymmetric information can be jointly used to explain tranching in specific deals: the senior tranche could be driven by information asymmetries, while multiple junior tranches might be designed to exploit particular investor's risk appetites.

Even though the most well-known LBOs are large transactions, based on the acquisition of public target firms, they are taken privately after the purchase of the target shares by the SPV. In addition, although 
LBO transaction is expected to be reversed with a public offering, most of the targets are held privately. As private borrowers are likely to be more opaque, loan tranching has the potential, through subordination, to be an important mechanism of securing large loans. Hence, tranching allows banks to create tranches with different risk-return profiles to meet, as closely as possible, the needs of different lenders/investors involved..$^{10}$ Lenders with high-risk aversion participate in senior loans while lenders with relatively higher risk tolerance participate in junior tranches.

The literature on syndicated loans addressing tranching is scant. Esty and Megginson (2003) show that loan syndicates of tranches extended to project finance deals are more concentrated in countries with better credit protection. Maskara (2010) finds that after controlling for tranched loans' risk characteristics, tranched deals have lower spreads than comparable non-tranched deals in the U.S. The author also shows that the benefits of tranching are higher for riskier borrowers. Cumming et al. (2020) show that strong creditor rights and better legal enforcement promote tranching, facilitating firm debt financing. Considering that LBOs are highly leveraged operations, the benefits of tranching are expected to be more visible than in other on-balance-sheet financing operations via syndicated lending. This leads us to hypothesize:

Hypothesis 4 [H4]: Loan tranching in LBOs reduce borrowing costs by reducing market incompleteness and information asymmetries.

\subsubsection{Term structure of loan spreads}

Extant empirical literature on syndicated loans' pricing presents puzzling results regarding the term structure of spreads. Bae and Goyal (2009), Maskara (2010), and Lin et al. (2011) show that, on average, there is a significantly positive relationship between spreads and maturity. Similar findings are presented by Ivashina and Kovner (2011) and Colla et al. (2012) for samples of loans for LBOs only. However, focusing on project finance loans, Sorge and Gadanecz (2008) document that the term structure of spreads is 'hump-shaped'. In project finance, investment projects usually start by generating revenues after a relatively long construction period. As loan repayment relies primarily on the project's cash flows,

\footnotetext{
${ }^{10}$ LBOs' debt can be classified as senior debt (25-45\%), subordinated debt (10-25\%) and mezzanine financing, with
} each category having tranches with different contractual structures and seniority levels. 
obtaining credit for longer maturities might be critical to ensure a project's financial viability. Similarly, Marques and Pinto (2020) find non-linear relationships between credit spreads and maturity for structured finance bonds.

Considering that LBOs, along with project finance and asset securitization, are classified as structured finance transactions and thus make use of an SPV (Caselli and Gatti 2005; Fabozzi et al. 2006; Leland 2007), and that structured financing loans are characterized by much longer maturities than corporate purpose or capital structure loans (Kleimeier and Megginson 2000), we would expect the term structure of spreads for loans in LBOs to behave differently from that of other on-balance sheet syndicated loans. This leads us to hypothesize:

Hypothesis 5 [H5]: The term structure of spreads in LBO loans differs from that of corporate financing loans.

Finally, it is particularly important to observe how our results regarding hypotheses H4 and H5 change in market- versus bank-based financial systems and in normal versus crisis times.

\section{Data, methodology, and variable definition}

\subsection{Sample selection}

Our sample consists of individual loans (or tranches) extracted from DealScan database for the 2000-2016 period. Information is available on the micro characteristics of the loans (e.g., deal and tranche size, maturity, currency, pricing, rating, type of interest rate) and of the borrowers (e.g., name, nationality, industry sector). While DealScan contains detailed historical information on virtually the entire population of syndicated loans closed in international capital markets, we only examine loans with a deal specific purpose code of 'leveraged buy-out'. We have excluded loans with no tranche amount or deal amount available and deal status 'not closed' or 'not completed'. We require that each deal must include at least one term loan. As the unit of observation is a single loan tranche, multiple issues for the same deal appear as separate observations in our database. We thus verified with Thomson Reuters that the primary purpose of each loan is the same for each specific deal, and that the sum of all loans in the package equals the deal amount. We also excluded deals closed by financial firms. In addition, since we wish to analyze the pricing 
of loans for LBOs, we have selected from our full sample (see Table A.2) those tranches with information available on spread. A close analysis of our loan data indicates the existence of some extreme values for the spread, time to maturity, and deal amount. We have trimmed these variables at the top and bottom $1 \%$ percentiles. Our final sample includes 11,111 loans (worth \$1,626.1 billion), which correspond to $79.0 \%$ of our full sample by volume and $77.2 \%$ by number. We have no reason to believe that this sample constraint introduces systematic bias in our main model. However, we conduct robustness checks in section 5.1, employing a generalized Tobit model following Heckman (1979).

Data on macroeconomic variables, such as market volatility and slope of the yield curve, were obtained from Datastream. We linked the macroeconomic variables and the microeconomic information contained in the loans based on the active date. Finally, in order to analyze the impact of acquired firms' characteristics on spreads and pricing processes, we have collected target firms' accounting and market data for the pre-LBO financial year from Datastream. As DealScan database does not provide an identification code, we hand matched firms in both databases by using the target name. We linked loan to target characteristics around the deal closing date (the closest fiscal year end in the period [-365 days to +30 days]). We also require that the targeting firms' size is higher than $\$ 100$ million.

Table 1 presents the distribution of loans for LBOs across borrower's nationality and industry. Panel A of Table 1 reveals that LBO lending is concentrated in the U.S. and Western Europe, with 51.21\% (49.74\%) and 40.76\% (43.97\%) of the total value (number) of LBO loans, respectively, which is consistent with the argument that LBOs are structured finance transactions more commonly used in countries with developed capital markets and relatively low country risk. Since LBOs are expected to result in future public offerings, this would mainly happen in countries characterized by developed and liquid equity markets. Panel B of Table 1 shows that LBO lending is highly concentrated in five key industries; i.e., manufacturing $(35.11 \%)$, services $(29.72 \%)$, retail trade $(8.84 \%)$, communications $(6.97 \%)$, and utilities (5.71\%) sectors account for $86.35 \%$ of all LBO lending value and $86.88 \%$ of all loans.

\section{***** Insert Table 1 about here $* * * *$}


Table A.3 provides information on top lead banks and their relative importance in LBO markets (Panel A), as well as on the composition of debt in market- versus bank-based financial systems. Panel A shows that the top ten lead banks, lending to firms located in countries with a bank-based financial system, are involved in a higher percentage ( $44.76 \%$ versus $32.66 \%$ for those located in a market-based financial system), by volume, of all syndicated loans. ${ }^{11}$ According to Panel B, almost half of total LBO debt is provided as Term loans B, or higher, in market-based financial systems. In both systems, Term loans (both first and second lien) and revolving credit facilities compose the bulk of LBO financing, accounting for about $87 \%-91 \%$ of the entire deal.

\subsection{Methodology and variables}

To analyze if LBO loans in market-based vis-à-vis bank-based financial systems are priced in segmented or integrated debt markets and to determine which factors drive LBO loan spreads, we follow an instrumental variable approach to address maturity and spreads being jointly determined. LBO deals are naturally characterized by endogeneity concerns since SPV directors manage a large set of variables simultaneously. Considering that LBOs are highly leveraged transactions, obtaining credit for longer maturities and with affordable spreads might be critical to ensure the acquired firm financial viability. We can thus assume that both spread and maturity are determined simultaneously once negotiations for the financial package begin. We confirm that maturity is endogenous by estimating the Durbin-Wu-Hausman chi-squared test. We reject the null hypothesis that maturity is exogenous to spread as we obtain a chisquared test statistic of 478.51 ( $p$-value $=0.000)$. We use the model described in equation $(1){ }^{12}$ The dependent variable is the Spread, in basis points. We employ GMM regression techniques and use the tranche size and if the loan is tranched as instruments for maturity. The 2008 financial crisis and the subsequent

\footnotetext{
${ }^{11}$ It is interesting to note that: $(i) 4$ lead banks (Credit Suisse, Goldman Sachs \& Co, Lloyds Bank, and Deutsche Bank $\mathrm{AG}$ ) are in the top 10 for both financial systems; and (ii) although top lead banks arrange deals across the two financial systems, they typically fall within the home financial system $-77.81 \%(67.02 \%)$ of the deals, by volume, closed in market-based (bank-based) financial systems are also arranged by top lead banks with headquarters in such a system.

12 We use a reduced-form model along the lines of existing pricing models for corporate bonds (e.g., Campbell and Taksler 2003; Chen et al. 2007; Marques and Pinto 2020) and loans (Carey and Nini 2007; Qian and Strahan 2007; Daniels and Ramirez 2008; Bae and Goyal 2009; Bharath et al. 2011; Lin et al. 2011; Lim et al. 2014).
} 
European sovereign debt crisis manifested a shortage of liquidity, which was reflected in a maturity reduction for loans. Since during the crisis period banks lost balance sheet capacity to lend, particularly for longer periods, it is plausible to associate maturity with both tranche size and if the loan is tranched for syndicated loans for LBOs. Larger tranches might imply lower maturities since they constitute a larger share in lenders' loan portfolio. The debt maturity literature regarding corporate bonds (Berger et al. 2005; Bali and Skinner 2006) highlights the importance of information asymmetry in the debt maturity decision. Hence, tranching increases loans' maturity by reducing the deadweight costs of asymmetric information (DeMarzo 2005). Due to time varying risk premia and as our analysis is conducted by tranches, we estimate standard errors clustered by year and deal, and estimate a regression of the following form:

$$
\begin{aligned}
\text { Spread }_{i, t}=\alpha_{0}+ & \alpha_{1} \text { Financial system }_{i, t}+\alpha_{2} \text { Laws and institutions }_{i, t}+\alpha_{3} \text { Financial crisis }_{t} \\
& +\alpha_{4} \text { Tranching }_{i, t}+\alpha_{5} \text { Term structure }_{i, t}+\alpha_{6} \text { Contractual controls }_{i, t} \\
& +\alpha_{7} \text { Syndicate structure }_{i, t}+\alpha_{8} \text { Firms }^{\prime} \text { characteristics }_{i, t-1} \\
& +\alpha_{9} \text { Macroeconomic controls }_{t}+\varepsilon_{i, t}
\end{aligned}
$$

where the subscripts refer to loan $i$ at time $t$. A discussion of the variables used follows. Table 2 provides the detailed definitions and sources for all the variables used, as well as the expected impact of explanatory variables on spreads. Summary descriptive statistics of the variables used are presented in Table A.4. ${ }^{13}$ Of the 11,111 loan observations, 10,731 loans (96.58\%) are part of a multi-tranche deal. The deal with the largest number of tranches has 16 loans, with an average/median number of tranches in our sample of 4 . The largest syndicated deal (loan) is $\$ 12.2$ billion ( $\$ 7$ billion) and the smallest is for $\$ 9.1$ million ( $\$ 0.6$ million). The average (median) spread is 353 bps (325 bps), while an average (median) loan matures in 6.2 years (6 years).

\section{**** Insert Table 2 about here ****}

\subsubsection{Dependent variables}

The spread corresponds to the price for the risk associated with the loan at closing, defined as the all-in-spread-drawn (AISD) above Libor or Euribor. The AISD is the interest rate that the borrower pays to

\footnotetext{
${ }^{13}$ In unreported univariate statistical analysis, we compare the distribution of variables and find that spread and most of the common pricing characteristics in fact differ significantly, not only between loans closed in bank-based and market-based financial systems but also among loans extended in the pre- versus crisis-period. Therefore, we would expect the impact on pricing to be market- and time-specific.
} 
the lender on the amount drawn on the loan, measured as a markup over a benchmark. ${ }^{14}$ Loans differ in the currency in which they are denominated, raising the possibility that expectations about exchange rate movements might drive differences in loan spreads across markets. We address this problem by converting contract spreads into dollar-equivalent spreads using, as proposed by Carey and Nini (2007), forward exchange rates as of the loan contract signing date. For syndicated loans, the AISD does not represent the full economic cost of credit of an LBO transaction, as there are, typically, several tranches funding a deal. We test the robustness of our results, in section 5.3, by aggregating tranches at the deal level and analyzing the determinants of the weighted average spread (WAS).

\subsection{2. $\quad$ Core independent variables}

We begin by addressing the core independent variables, those directly related to the testing of our hypotheses. In order to test hypothesis H1, we use an indicator variable that takes the value one for loans extended to borrowers in market-based financial systems. ${ }^{15}$ Since access to debt financing and future exit options are central issues in LBOs (Cao et al. 2016), we expect the type of financial system - market-based or bank-based - to influence the pricing of loans extended to these structured finance transactions. In addition, as banks have comparative advantages in mitigating asymmetric information problems by monitoring borrowers more closely and are able to enforce contracts without judicial assistance by exercising contractual covenants, we expect borrowers in countries with market-based financial systems to face higher loan spreads.

Concerning hypothesis H2, Qian and Strahan (2007), Bae and Goyal (2009), and Lin et al. (2011) offer evidence that stronger creditor rights result in loans with lower spreads. Considering that bankruptcy laws define who controls the insolvency process and has rights to the property of a bankrupt firm, and with what priority, we expect stronger creditor rights, proxied by Djankov et al.'s (2007) creditor rights index, to decrease loan spreads. In the context of LBOs, shareholder protection law is of higher importance in

\footnotetext{
${ }^{14}$ DealScan defines the AISD as 'the amount the borrower pays in basis points over LIBOR for each dollar drawn down. It adds the spread of the loan with any annual (or facility) fee paid to the bank group.'

${ }^{15}$ We determine the nationality of the borrower by the country in which the target firm is incorporated.
} 
safeguarding external shareholders' interest. We use the antidirector rights index (La Porta et al. 1998; Spamann 2010) as a measure of shareholder protection and expect that stronger laws governing shareholder rights increase loan spreads. Finally, Bay and Goyal (2009) show that enforceability matters for loan contracting, and not merely the existence of creditor rights. The ability of lenders to enforce (or threaten to enforce) contract clauses or to seize collateral are important determinants of loan spreads. Our measure of enforcement efficiency comes from La Porta et al. (1998) and we expect that loans extended to countries with superior enforcement have lower spreads.

In order to test our third hypothesis (H3) we include a dummy for crisis, which captures the period of the 2008 financial crisis and the subsequent European sovereign debt crisis. We expect a significantly positive relationship between this dummy and the borrower's economic cost of credit.

The syndicate deal structure is layered so that each position benefits from the credit protection of all the positions subordinated to it. In order to test hypothesis H4, we need to measure a LBO deal's tranching. As in Maskara (2010) and Cumming et al. (2020), we use the number of tranches, an ordinal variable that ranges from 1 to 16 depending on the number of tranches within the deal, and expect a negative impact on spread.

To investigate the term structure of spreads - hypothesis H5 -, we include loan maturity and the logarithm of maturity as explanatory variables. As for other structured finance securities, we expect to find a non-linear relationship between loan spreads and time to maturity.

\subsubsection{Contractual controls}

Recent empirical studies indicate that several contractual factors convey information about the pricing of loans and bonds (Campbell and Taksler 2003; Carey and Nini 2007; Chen et al. 2007; Qian and Strahan 2007; Bae and Goyal 2009; Maskara 2010; Bharath et al. 2011; Lin et al. 2011; Mattes et al. 2013; Lim et al. 2014; Firestone and Rezende 2016). These include credit rating, deal size, currency risk, loan and interest rate type, and fees.

Credit ratings are a central determinant of bond and loan spreads. As the information on loan ratings provided by DealScan is not available for several tranches, we include the dummy variable rated, equal to 1 if the loan has a credit rating from $\mathrm{S} \& \mathrm{P}$ and/or Moody's, and 0 otherwise. For those tranches with at least one credit 
rating assigned by $\mathrm{S} \& \mathrm{P}$ or Moody's, we converted credit ratings as follows: $\mathrm{AAA}=\mathrm{Aaa}=1, \mathrm{AA}+=\mathrm{Aa} 1=2$, and similarly until $\mathrm{D}=21$. If a tranche has two credit ratings, we computed the average. Rating scales are inverse scales, so we expect spreads to increase as the rating decreases.

Colla et al. (2012) find that seniority is reflected in pricing; i.e., the differential between junior and senior spreads is influenced by the relative mix of senior to junior debt. We use the subordinated dummy variable to control for differences in risk existing among different tranches of a deal. We expect subordinated loans to have higher spreads than senior loans.

The deal size is, ceteris paribus, positively related with lower uncertainty and higher liquidity than smaller offerings (Kleimeier and Megginson 2000; Chen et al. 2007; Sorge and Gadanecz 2008; Bae and Goyal 2009; Ivashina and Kovner 2011; Colla et al. 2012). We thus expect a negative impact of deal size on spread. We expect tranches exposed to currency risk to have higher spreads than those that are not (Kleimeier and Megginson 2000). Finally, we control for the following dummy variables: term loan and fee information (Lin et al. 2011; Colla et al. 2012). ${ }^{16}$ We expect to observe a significant and positive relationship between these variables with spread.

\subsubsection{Syndicate structure}

Literature concerned with the topic of relationship banking argues that repeated borrowing from the same lender reduces information asymmetries about the borrowing firms' characteristics, therefore affecting the terms of financing (Boot 2000; Sufi 2007). Petersen and Rajan (1994) and Berger and Udell (1995) find that banking relationships are associated with better financing conditions. Regarding the syndicated loan market, Dahiya et al. (2003), Bharath et al. (2007, 2011), Ivashina (2009), and Alexandre et al. (2014) obtained similar findings: relationship banking positively affects lending terms. Ivashina and Kovner (2011) show that an increase in bank relationship strength is associated with a decrease in the spread of loans extended to LBOs sponsored by private equity firms. As bank relationships mitigate deadweight

\footnotetext{
${ }^{16}$ A term loan tranche is a loan facility for a specified amount, fixed repayment schedule and maturity, and is usually fully funded at origination. A credit line or revolver facility have shorter maturities than term loans and are drawn down at the discretion of the borrower (Lim et al. 2014).
} 
costs of asymmetric information, we expect a negative relationship between a former lender and loan spreads.

Esty and Megginson (2003) argue that smaller and more concentrated syndicates have better monitoring incentives and greater re-contracting abilities. The syndicate size is proxied by the number of lenders in a deal syndicate and, as syndication may improve risk sharing, we expect a negative impact on spreads (Ivashina and Kovner 2011). Additionally, Bae and Goyal (2009) find for non-U.S. borrowers, that foreign participants in loan syndicates increase spreads. On the contrary, foreign bank participation in loans extended to U.S. borrowers is associated with greater competitive pressures during the bidding process, which reduces spreads. We examine this impact by including a dummy control for domestic lead banks (versus foreign lead banks). To capture additional differences in bank syndicates, we also control for bank reputation, computed according to the yearly Thomson Reuters mandated arrangers' ranks (Ivashina and Kovner 2011). As the involvement of lead banks with a higher reputation may reduce information asymmetries, we expect a negative relationship between lead bank reputation and spreads.

\subsubsection{Target firms' characteristics}

From the literature related to the determinants of LBO activity, we borrow several variables that proxy for size, cash flow generation, asset tangibility, growth opportunities, leverage, profitability, and credit risk of target firms (e.g., Opler and Titman 1993; Renneboog et al. 2007; Boubaker et al. 2014; Cao et al. 2016). Colla et al. (2012) find that LBO debt structures are explained not only by market condition but also by the target firms' characteristics, namely by the target firms' pre-LBO profitability. Extant empirical literature on debt pricing provides evidence regarding the impact of borrowers' characteristics on spreads (Campbell and Taksler 2003; Chen et al. 2007; Qian and Strahan 2007; Bae and Goyal 2009; Flannery et al. 2012). After highlighting these studies, we expect a negative impact of total assets, fixed assets-to-total assets, ROA, market-to-book, FCF-to-total assets, and Z-score variables, on spreads, but a positive relationship between total debt-to-total assets ratio and spreads.

\subsubsection{Macroeconomic controls}


We control for other country-level variables, such as GDP per capita and the S\&P's country rating to control for sovereign risk (Kleimeier and Megginson 2000; Qian and Strahan 2007; Bae and Goyal 2009; Lin et al. 2011). We also control for macroeconomic factors such as the term structure of interest rates, 5YrTB-3mTB, calculated as the difference between the 5-year and 3-month U.S. T-bill rate at the deal closing date, and market volatility, measured by the Chicago Board Options Exchange Volatility Index (Campbell and Taksler 2003; Titman et al. 2004; Colla et al. 2012). Kaplan and Strömberg (2009) provide evidence that valuation ratios in LBOs follow the economic cycle very closely. This finding is corroborated by our data. As can be seen in Table A.2, there is a limited sample of transactions in tight credit markets. Finally, to control for structural differences across industries, we use industry fixed effects.

\section{The pricing of loans for LBOs}

\subsection{Are loans for LBOs priced in integrated debt markets?}

A Chow test for a structural break is used to investigate whether the spreads associated with loans extended to borrowers located in market- versus bank-based financial systems are influenced differently by common pricing factors. In essence, we are testing whether the pricing characteristics used in equation (1) are significant in both markets and, if so, whether they have the same coefficient values. The Chow test statistic of 13.21 exceeds its critical level, indicating that loans for LBOs closed in market-based financial systems rather than in bank-based financial systems are priced in segmented debt markets, which corroborates hypothesis H1. We thus analyze, in section 4.2., the pricing determinants of loan spreads separately for each sub-sample. The same methodology was used to determine if loans for LBOs closed in the pre- vis-à-vis crisis-period are influenced similarly by common pricing factors. Again, the Chow test statistic of 187.52 (124.15 and 36.61 for market-based and bank-based sub-samples, respectively) exceeds its critical value, indicating that loans have different pricing processes in these two periods. We thus corroborate hypothesis H3. We investigate further this hypothesis in section 4.3. 
In models [1] and [2] of Table 3, we use equation (1) and examine whether the spreads on loans closed in the two financial systems are significantly different, for a sample of 11,111 loans. ${ }^{17}$ Findings suggest, as expected, that loans for LBOs extended to borrowers in market-based financial systems have higher spreads, holding other factors constant, than those extended to borrowers in bank-oriented countries. We show that, even controlling for countries' law and institutional characteristics, there exist significant differences in the cost of borrowing between systems in which financial intermediaries play the dominant role and those where they do not: the market-based dummy variable is associated with a 163.96 bps spread increase in model [2].

\section{**** Insert Table 3 about here ****}

Overall, we accept the hypothesis (H1) that pricing processes differ significantly in the two financial systems. In line with Demirgüç-Kunt and Levine (1999), Chakraborty and Ray (2006) and Ergungor (2008), we show that the financial structure matters. Moreover, so far our results are not consistent with the law and finance approach (La Porta et al. 1998, 2000) that stresses the primacy of the legal system: the type of financial system affects firms' cost of borrowing when controlling for investor rights and enforceability of contracts.

\subsection{Determinants of loan spreads}

In this section, we investigate the determinants of loan pricing in LBOs. Considering that loans for LBOs are priced differently in market-based and bank-based financial systems, we study the pricing for each sub-sample separately. Models [3] and [4] present loan pricing regression results for sub-samples of 7,944 and 3,167 loans extended to borrowers in market-based and bank-based financial systems, respectively, with adjusted $\mathrm{R}^{2}$ values of 0.89 and 0.71 .

We start by analyzing the impact of core variables on spreads. Concerning variables capturing law and institutional characteristics, results in model [3] for deals closed in market-based financial systems, show that the impact of the creditor rights index, as expected, is negative and significant. Likewise, loans

\footnotetext{
${ }^{17}$ In this section, we do not distinguish between a firm's attributes because of the significant sample size reduction that it would impose from 11,111 to 2,141 observations. We control for acquired firms' characteristics in section 5 .
} 
extended to borrowers in countries with superior enforceability of contracts have lower spreads. With better protection, lenders can control borrowers' risk because they know they will be able to take assets in the event of default. However, the index of antidirector rights, which proxy for equity investor protection, has an insignificant impact on loan spreads. For loans extended to borrowers in bank-based oriented countries, in model [4], we find that the level of development of the country's contracting environment are not significantly related with LBO loan spreads. Overall, our results are consistent with the emphasis on the importance of the legal system, mainly on creditor's protection and enforceability of contracts, on financing for loans closed in a market-based financial system (La Porta et al. 1998, 2000), but not for those extended to borrowers in a bank-based financial system. We thus validate hypothesis H2.

As expected, the 2008 financial crisis and the subsequent European sovereign debt crisis have imposed a significant increase in spreads for loans in LBOs. A transaction with an active date during the crisis period observes a higher average spread of $149.14 \mathrm{bps}$ and $209.72 \mathrm{bps}$ for loans arranged in marketbased and bank-based financial systems, respectively. ${ }^{18}$

We find, as expected, that tranching is reflected in pricing: number of tranches are significantly negatively related for both sub-samples. That is, the greater the number of tranches, the lower the credit spread, after adjusting for the other factors included in the regression. Our results are in line with the predictions of security design (Duffie and Rahi 1995; Riddiough 1997) and contractual finance (Maskara 2010; Cumming et al. 2020) literature: tranching allows banks to create loan facilities with different characteristics to respond to different invertor/lender risk-return profiles. We thus corroborate our hypothesis $\mathrm{H} 4$ that loan tranching in LBOs, by reducing market incompleteness and information asymmetries, reduce loan spreads.

The seventh line of Table 3 details the influence of maturity on spread. Similar to Ivashina and Kovner (2011) and Colla et al. (2012), we show a significantly positive relationship for loans closed in both financial systems. The coefficient values indicate that issuing a loan, with an original maturity one year longer than the mean, increases spread by 76.95 and 111.69 bps in market-based and bank-based financial

\footnotetext{
${ }^{18}$ We also run unreported specifications including year fixed effects instead of the crisis dummy variable, with similar results.
} 
systems, respectively. We investigate this effect further in section 4.4., where we examine if there is any non-linear relationship between spread and maturity.

Regarding the impact of control variables, model [3] shows that rated loans have lower credit spreads and the higher the credit risk, the higher the spread. While a rated loan extended to a borrower located in a country with a market-based financial system has a lower spread of 122.86 bps than a not-rated one, a one unit increase in credit rating (corresponding to a downgrade from AAA to AA+) is associated with an increase of 8.00 bps in spreads. Neither rated nor rated*rating variables influence spreads for LBO loans closed in bank-based financial systems. Unfortunately, credit risk information for loans arranged for borrowers in bank-based financial systems is very scant, which might explain the insignificant relationship between spread and credit risk.

We find, as expected, that seniority determines spreads: subordinated tranches have higher spreads than senior ones. That is, the greater the subordination level, the higher the credit spread. This reflects the structuring features of an LBO transaction. The structure is layered so that each position benefits from the credit protection of all the positions subordinated to it; i.e., each senior tranche has absolute priority in the cash flow over the more junior classes. While spread and deal size are negatively and significantly related for loans in market-based financial systems, they have an insignificant impact for loans in bank-based financial systems. Our results corroborate those of Ivashina and Kovner (2011), which interpret the significant negative relationship between deal size and spread of LBO loans extended to U.S. borrowers as evidence of a positive price liquidity effect related to the size of the entire deal. Regarding the bank-based sample, our results are in line with those of Colla et al. (2012), who find an insignificant impact of deal amount on loan spread for a sample with deals extended for borrowers in both financial systems.

The influence of currency risk on spread is, as expected, positive and significant but in model [4] only. Such a mismatch in the currency of the deal's nationality and the currency of the loan increases significantly the rate charged by 50.32 bps for loans extended to borrowers located in bank-based financial systems. Contrary to Colla et al. 's (2012) results, we show that the tranche type does not influence spreads, after controlling for other contractual, syndicate and institutional characteristics. In addition, and as we 
expected, loans with fee information have higher spreads for loans extended to deals closed in bank-oriented countries, which might suggest that in these countries risk is priced jointly through spreads and fees.

Regarding variables that reflect the syndicate structure, we find that while bank relationships do not affect loan spreads in model [3], there is a significantly negative impact of the variable former lender on loan spreads for loans closed in bank-based financial systems. Hence, our results do not corroborate the findings of Ivashina and Kovner (2011), who show that relationship banking positively affects lending terms in loans closed in the U.S. As expected, spread and the number of lenders are negatively and significantly related for all loan sub-samples. A larger number of banks involved may lower the spread because this may be associated with an increase in the certification of the transaction and thus mean that a higher number of banks will share default risk. We find that if the syndicated deal is arranged by a domestic versus a foreign bank, it does not affect loan pricing in both financial systems. Finally, while credit spread and bank reputation have an insignificant relationship for loans extended to borrowers in bank-based financial systems, the better the lead bank reputation, the higher the spread in model [3]. These results are in line with those presented by Ivashina and Kovner (2011) for the market-based sub-sample, which can be explained by the fact that most reputable banks might extract rents from the borrower and charge higher borrowing costs, as they provide superior guarantee for the success of the LBO and a greater capacity to finance the operation through debt.

The country risk is insignificantly related to spreads, while borrowers located in countries with a market-based financial system and a higher GDP per capita pay higher spreads. Contrary to the results of Sorge and Gadanecz (2008) and Marques and Pinto (2020), spread and the yield curve slope, 5yTB-3mTB, are significantly positively related for loans extended to borrowers in market-oriented financial systems, meaning a steeper yield curve is associated with higher spreads. This can be explained by the fact that against a background of economic growth and consequent rises in interest rates, banks tend to reduce the required spreads for all credit risk levels. In line with Colla et al. 's (2012) findings, market volatility has a significantly positive impact on spreads in models [3] and [4].

We perform a variety of econometric tests to assess the relevance and validity of our instruments. These tests and their results are presented at the bottom of Table 3. As mentioned in section 3.2, we 
implement GMM regression techniques and use the tranche size and if the loan is tranched as instruments for maturity. To test if our instruments are relevant, we conduct Anderson's LR test of the null hypothesis that correlations between instruments and the endogenous variable are essentially zero. We reject the null hypothesis for the four models presented in Table 3, implying that the instruments are strongly correlated with maturity. We also estimate the Hansen's $J$-statistic for over-identification restrictions. The reported statistics indicate that the over-identifying restrictions are not rejected, which provide support to the exogeneity of the tranche size and if the loan is tranched. We can thus conclude that our instruments are relevant and valid.

\subsection{The impact of the financial crisis on spreads}

In order to investigate if our results change in normal versus crisis times, namely to examine if borrowers and lenders involved in LBOs changed their attitude in terms of pricing and compensation, we re-estimate models in Table 3 including the interaction terms between the crisis dummy and core variables. Crisis dummy is equal to 1 if the closing date falls within the 2008 financial crisis and the subsequent European sovereign debt crisis period, from September 15, 2008 (Lehman Brothers' bankruptcy filing date) to December 31, 2016, and 0 if it falls within the pre-crisis period, from January 1, 2000 to September 14, 2008. Starting with the estimation results for a sample with all loans - model [5] -, Table 4 shows, consistent with the previous results, that in general borrowers in countries with market-based financial systems face higher spreads than borrowers located in countries with bank-based financial systems. However, this difference is reduced in the crisis period. While in the pre-crisis period, loans extended to borrowers in market-based financial systems have, on average, 176.01 bps higher spreads, in the crisis period this difference decreases, since the interaction term between market-based and crisis dummy variables is associated with a statistically significant 81.45 bps decrease in spreads. We perform a $t$-test and reject the null hypothesis that the sum of these coefficients is equal to zero ( $t$-statistic of 6.87 ). In the crisis period, loans to LBOs closed in market-oriented countries have, on average, 94.55 bps higher spreads than those closed in bank-based ones. Results also show, with the exception of the index of antidirector rights, that the 2008 financial crisis and the subsequent European sovereign debt crisis affect significantly the magnitude 
of the impact of our core variables on loan spreads. So far, our results corroborate Carey and Nini's (2007) findings that the loan market is not globally integrated, as loans in market-based financial systems have higher spreads vis-à-vis those extended to borrowers in bank-based financial systems.

\section{**** Insert Table 4 about here $* * * *$}

Regarding the impact of the core variables and their interactions with the crisis dummy, Table 4 shows that differences in pricing between loans closed in market-based - models [6] - versus bank-based - model [7] - financial systems, for both pre- and crisis periods, are related to countries' law and institutional characteristics in which LBO deals are closed. In particular, the coefficient of the number of tranches is negative and significant in both models for the pre-crisis period and this impact is not affected by the 2008 and the subsequent European sovereign debt crisis. We thus corroborate hypothesis H4 that loan tranching in LBOs reduce loan spreads not only per financial system, but also for the two time periods. In addition, despite that the coefficient of the interaction term between the crisis dummy and the loan's time to maturity is significant and negative, there is still a significantly positive relationship between maturity and spreads for loans closed in both market- and bank-based financial systems, during the crisis period. ${ }^{19}$

Creditor rights and enforcement indexes are negatively associated with loan spreads in model [6] for both pre- and crisis periods. This effect for loans extended for borrowers in market-based financial systems is stronger in the pre-crisis period than in the crisis period. Similarly, loans extended to borrowers in countries with superior enforceability of contracts have lower spreads, whereas the coefficient of the interaction term between enforcement and crisis is significant and positive. These results can be explained by a change, between pre- and crisis-period, in the type of factors that explain loan spreads from contractual (term loan and fee information), syndicate structure characteristics (number of lenders and bank reputation) and institutional characteristics to a certain extent, to risk (rated and rated ${ }^{*}$ rating) and macroeconomic factors (country risk and market volatility).

\footnotetext{
${ }^{19}$ Although not reported, we perform t-tests and reject the null hypothesis of the sum of core variables' coefficients and those of their interaction with the crisis dummy are equal to zero.
} 
For loans extended to deals in bank-oriented countries, in model [7], we find that the level of creditor rights is not significantly related with spreads in both pre- and crisis period. While the coefficient of enforcement is insignificant, the coefficient of the interaction term between crisis dummy and enforceability index is positive and significant. This means that loans extended to LBO deals closed in countries with superior enforceability of contracts pay higher spreads in the crisis period. Although it is contrary to what we expected, this result may be explained by the fact that during the crisis period, LBO deals were closed in countries with a higher enforceability index. With a significant increase in spreads in the crisis period, as a result of the sharp reduction in bank liquidity and generalized increase in credit risk, we would expected a spread increase for these loans. Finally, as in models [3] and [4] of Table 3, the index of antidirector rights has an insignificant impact on loan spreads extended to LBO deals closed in both financial systems and time periods. Overall, our results corroborate hypotheses $\mathrm{H} 2$ for both pre- and crisis periods. Results suggest that stronger creditor protection and enforceability of contracts environment in LBOs reduce borrowing costs for loans closed in market-based financial system, but not for those extended to borrowers in bank-based financial systems. Moreover, the improvement is larger in the pre-crisis period.

\subsection{The term structure of spreads}

So far, results in Tables 3 and 4 corroborate those of Ivashina and Kovner (2011) and Colla et al. (2012), which show that lenders receive higher remuneration for being exposed to risk for a longer period of time. Considering that, the term structure of spreads for syndicated loans appears as a particular puzzle, to investigate hypothesis $\mathrm{H} 5$ further, we re-estimate models [5] to [7] by including the natural logarithm of maturity (log maturity) as an additional variable in the models to test for the presence of any non-linear effects of maturity on spreads.

Regression results are presented in Table 5. A convex relationship between spreads and maturity is found in model [8] for all loans, as plotted in the top panel of Figure 1 (Graphs A and B), for both pre- and crisis periods. Results remain unchanged when re-estimating model [8] for sub-samples created based on whether the borrower is located in a country with a bank-based vis-à-vis a market-based financial system: models [9] and [10], as demonstrated in the middle and bottom panels of Figure 1, show a convex term 
structure of spreads in loans for LBOs. In the pre-crisis period, while maturity and spread have a significant and positive relationship, the coefficient of the logarithm of maturity is significant but negative. For the crisis period, we find a weakening in the impact of both loan maturity and the logarithm of maturity on loan spreads: the coefficient of the interaction term between the crisis dummy and maturity is negative, whereas the coefficient of the interaction term between the crisis dummy and the logarithm of maturity is positive. From these results we conclude that (i) between pre- and crisis period, there is not only a shift of the interest rate curve upwards, but also a shift to the right of the curve's minimum spread; and (ii) the non-linear relationship between spread and maturity is considerably more pronounced for the bank-based sub-sample.

**** Insert Table 5 and Figure 1 about here ****

The convex relationship, a "smile" effect, between credit spread and maturity can be explained by the intrinsic characteristics of LBO transactions and by loan market effects. Firstly, liquidity risk and leverage effects explain the higher short maturity spreads. According to Caselli and Gatti (2005), LBOs constitute a merger and acquisition transaction 'that result in leaving the acquired company with a debt ratio that is higher than what it was before the acquisition.' Hence, the higher debt levels typical of these financing transactions allow for the exploitation of the financial leverage effect. LBOs increase financial risks, exposing management to higher pressures to guarantee the repayment of the debt and the debt service in the short-term. As loan repayment relies primarily on the acquired firm's cash flows, this short-term liquidity risk may explain why spreads are higher in shorter-term maturities than in longer maturities, where liquidity risk is lower due to higher cash-flow to debt service ratios. Spreads are hence lower for median maturities, but increase for longer maturities, justified by the higher risk embedded in longer term loans, demonstrating an upward-sloping relationship between maturity and spread similar to the one existent for general corporate purpose loans. An interesting extension to this study, but not possible using our available data, would be to analyze the loan spread relation to the EBITDA (or Cash-flow) to transaction value ratio, a proxy for the theoretical minimum approximated maturity to repay the loan with internally generated funds by the target firm. Secondly, supply and demand for loans may also explain this convexity and especially the observation of lower spreads in median maturities. Banks and investors compete more 
actively for median or standard maturities, where cash flow risk or liquidity is lower and where the higher risk effect of longer maturities is not observed.

The large amounts of debt financing in an LBO are obtained in the form of two major types of loans: term loans and credit lines. We thus re-estimated models [9] and [10] for two sub-samples created according to whether loans are term loans or credit lines and our results remain unchanged: we find a convex relationship, a "smile" effect, between spread and maturity. Our finding supports hypothesis H5. Contrary to traditional on-balance sheet syndicated loans, which typically have a significant and positive relationship between spread and maturity, the term structure of spreads in LBO loans are convex and, thus, non-linear.

Finally, results presented in Tables 4 and 5 allow hypothesis H3 to be validated: syndicated loan market dynamics change significantly in normal versus crisis times and thus, participants change their attitude in terms of pricing and compensation.

\section{Robustness Checks and Extensions}

\subsection{Sample selection}

There is a reduction in the number of observations (from 14,395 to 11,111 observations) when we select from our full sample those issues that have complete data on spread. Although, on average, we document a relatively high survival rate from the full sample to the sub-sample with information on tranche spreads, one important question arises: are the loans with complete information different from other issues with missing data on spread? Additionally, our sample includes loans signed by borrowers in Europe over the years 2000-2016. Since Europe experienced two crises during that period - the 2008 financial crisis and the subsequent European sovereign debt crisis - we cannot rule out that a flight to quality might have left many borrowers in these countries credit-rationed. As a result, the probability of observing loans for LBOs with relevant pricing information might not be random (along with our sample selection) but rather somewhat determined by the same risk characteristics that enter our pricing regressions.

Therefore, to ensure that our estimates are unbiased, we employ a generalized Tobit model, following Heckman (1979). We perform a maximum likelihood estimation on the spread samples of our model specifications (models [2] to [4]), simultaneously with a probit selection equation, where the 
probability of having a loan with complete information on spread is a function of micro and macro variables. We accept the hypothesis of equations being independent for all model specifications, concluding that we do not have a sample selection problem.

\subsection{The impact of the target firms' characteristics on spreads and pricing processes}

In this section, we augment our baseline specifications with acquired firms' characteristics to examine how they influence our previous results as well as loan spreads. After applying the screens mentioned in section 3.1, hand matching publicly traded firms acquired via LBO loans between 2000 and 2016, and winsorizing firms' characteristics at the 1st and 99th percentiles, we identified 788 unique firms for which we have all of the necessary data for the analysis (Table A.5).

Models [11], [12], and [13] in Table 6 show that our previous results remain unchanged when we include firms' characteristics as additional control variables. The results of model [11] show that borrowers located in countries with a market-based financial system face 143.96 bps higher spreads than borrowers located in countries with a bank-based financial system, holding other factors constant.

The impact of the creditor rights and enforcement indexes on spreads is significant and negative for acquired firms located in countries where financial markets play the dominant role - model [12] -, showing that better protected lenders face a lower cost of borrowing. On the contrary, the level of both creditor rights and enforceability of contracts do not affect loan spreads for LBOs closed in bank-oriented countries - model [13]. Moreover, the index of antidirector rights has an insignificant impact on loan spreads. These results are consistent with the importance of creditor's protection and enforceability of contracts in determining borrowing costs in market-based financial systems (hypothesis H2).

\section{**** Insert Table 6 about here $* * * *$}

The 2008 financial crisis and the subsequent European sovereign debt crisis have imposed a significant increase in spreads for loans in LBOs, while the creation of different tranches with different riskreturn profiles to match invertor/lender needs reduce loan spreads. This result regarding tranching corroborates, again, hypothesis H4: tranched loans have lower spreads vis-à-vis non-tranched facilities. 
Considering the impact of the acquired firms' characteristics on loan pricing, we find an insignificant relationship between leverage and spreads, contrary to Ivashina and Kovner (2011), who show a negative relationship using an U.S. setting, but in line with the results presented by Colla et al. (2012). A similar effect is obtained for variables that proxy for firms' size and growth opportunities. Similar to the results of Ivashina and Kovner (2011), we find an insignificant relationship between the cost of borrowing and the firms' capability to generate cash flows. We also corroborate Colla et al.'s (2012) findings that the pricing of debt in LBOs mostly depends on pre-LBO profitability. Furthermore, our results show that acquired firms with higher asset tangibility levels, as expected, face lower spreads for loans extended to borrowers in bank-based financial systems.

Finally, to investigate further the term structure of spreads we re-estimated models presented in Table 5 including acquired firms' characteristics as additional variables. Again, we find non-linear relationships between spread and maturity for all model specifications, which corroborates hypothesis $\mathrm{H} 5$. $^{20}$

\subsection{A deal-level analysis}

In this section, we aggregate tranches at the deal level and analyze the determinants of LBOs' cost of debt. We use the deal WAS, computed as the weighted average between the tranche spread and its weight in the deal size, as a proxy of the deal's overall cost of debt. The robustness of our results is tested by using the model specified in equation (2), in which the dependent variable is the WAS, in basis points. We employ GMM regression techniques, and use if the deal is tranched and the deal active year as instruments for maturity, and estimate a regression of the following form:

$$
\begin{aligned}
& \text { WAS }_{i, t}=\alpha_{0}+ \alpha_{1} \text { Financial system }_{i, t}+\alpha_{2}{\text { Laws and } \text { institutions }_{i, t}+\alpha_{3} \text { Financial }_{\text {crisis }} t}_{t} \\
&+\alpha_{4} \text { Tranching }_{i, t}+\alpha_{5} \text { Term }_{\text {structure }}, t, t \\
&+\alpha_{6} \text { Contractual controls }_{i, t} \\
&+\alpha_{7} \text { Syndicate structure }_{i, t}+\alpha_{8} \text { Firms }^{\prime} \text { characteristics }_{i, t-1} \\
&+\alpha_{9} \text { Macroeconomic controls } \\
&
\end{aligned}
$$

where the subscripts refer to deal $i$ at time $t$. Standard errors are clustered by year and firm.

Column 1 of Table 7 reports the results of the IV estimation of equation (2) for a sample of 3,239 deals with information on WAS. Findings suggest, as in previous sections, that LBO deals extended to

\footnotetext{
${ }^{20}$ Due to limited space, we do not show the results. However, the results are available from the authors.
} 
borrowers in market-based financial systems are associated with 79.28 bps higher cost of debt. Similar results are obtained when we augment our baseline specifications with acquired firms' characteristics model [17]. These results show that there are opportunities for firms to raise funds more cheaply using one financial system rather than the other or that there is evidence of a market inefficiency that needs to be corrected by regulation or legislation. While many of our variables are correlated with loan spreads, differences in spreads across the two financial systems remain even when we implement a deal-base analysis and control for target firms' characteristics. We believe this pricing difference is a puzzle and constitutes an important avenue of future research.

\section{**** Insert Table 7 about here $* * * *$}

Models [15] and [16] present regression results for sub-samples of 2,675 and 564 deals extended to borrowers in market-based and bank-based financial systems, respectively. Similar to what we find for loan pricing, while creditor rights and enforcement indexes have a significantly negative impact on WAS in market-based financial systems, this relationship is insignificant for deals extended to borrowers in bankbased financial systems. These results hold when we control, in model [18], for firms' accounting and market variables. The 2008 financial crisis and the subsequent European sovereign debt crisis increases significantly WAS in all models, whereas the weighted average maturity (WAM) does not affect pricing significantly in a deal-based analysis.

Contrary to what we found in the tranche-level analysis, for LBO deals extended to borrowers in market-based financial systems, there is a significant and positive relationship between the deal's number of tranches and its cost of debt. This result is supported by Maskara's (2010) theory on the economic value of tranching. As risky deals are more likely to be tranched, we should expect that deals with a higher tranching intensity to be riskier and thus have a higher overall cost of debt funding. Concerning contractual controls, while WAS and deal size are negatively and significantly related for loans in market-based financial systems, they have a significant and positive relationship for loans extended to borrowers in bankbased financial systems. As we expected, there is a significant relationship between currency risk and WAS. However, these variables do not impact WAS when controlling for acquired firms' characteristics. We also 
find that variables reflecting the syndicate structure affect WAS for the market-based sub-sample only: $(i)$ WAS and the number of lenders are negatively and significantly related; (ii) deals with a domestic lead bank have a lower cost of debt; and (iii) WAS and bank reputation have a significant and positive relationship. Finally, the GDP per capita impacts WAS positively in market-based sub-sample only, while the yield curve slope and market volatility have a significant and positive relationship with WAS for deals extended to borrowers located in countries with both financial systems. Results presented in Table 7 corroborate our main findings regarding hypotheses $\mathrm{H} 1$ and $\mathrm{H} 2$ when implementing tranche-level analyses. The impact of explanatory variables on WAS is different for LBOs closed in market-based vis-à-vis bank-based financial systems, and law and institutional characteristics are important determinants of LBO loan spreads for borrowers in market-based financial systems.

Regarding the impact of acquired firms' characteristics on WAS, model [18] in Table 7 shows that, as presented in section 5.2., return on assets ratio affects negatively the cost of LBOs' debt in deals closed in market-oriented countries, which is in line with the results presented by Colla et al. (2012). We also find that, as expected, the FCF to assets ratio influences significantly and negatively the deal's overall cost of debt for the market-based sub-sample. However, our results regarding the impact of leverage on WAS do not corroborate those of Colla et al. (2012), which find a significant and positive relationship.

\subsection{Additional sensitivity tests}

We perform a number of additional robustness checks that further control for a number of contractual features which were not included previously as that would impose a significant reduction in the number of observations, as well as for adjustments to our rating and country risk variables. First, spreads are not the only measure of risk premiums, because loans also carry fees that can be related to creditworthiness and performance. In LBOs, up-front and commitment fees are significant, with the first, paid to the lead bank for structuring and syndicating the loan, and are on average $1.5 \%-2 \%$ of the loan amount (Ivashina and Kovner 2011). Our baseline models are then re-estimated after adding commitment fee and upfront fee as additional controls. We find that both variables are significantly and positively correlated with spreads, which supports the idea that risk is priced jointly through spreads and fees. These 
findings are consistent with those presented in Gatti et al. (2013) and Berg et al. (2016). Second, we test the sensitivity of our results with the inclusion of secured dummy variable - that takes the value 1 if the loan is secured and 0 otherwise - and found that $(i)$ the relationship between spread and secured is significant and negative when re-estimating models [3], [4] and [5], and (ii) the main results do not differ from our baseline models. We also include covenant intensity as an additional variable and contrary to Colla et al. (2012), who find that spread and covenant intensity have a significantly negative relationship for loans in LBOs, we find an insignificant relationship for all sub-samples. Second, we test the sensitivity of the results by reclassifying the S\&P's ratings into five categories ranging from best to default, like the ones proposed by Corielli et al. (2010). Finally, we include the firms' Z-score, as proposed by Altman (1993), as an additional control variable in models [11] to [13]. We find an insignificant impact of Z-score on loan spreads, while the remaining acquired firms' characteristics maintain the same effect in terms of sign and significance. Overall, these additional sensitivity tests further confirm the robustness of our results.

\section{Summary and conclusions}

In this paper, we analyze the pricing determinants of loans for LBOs using a worldwide database of 11,111 loans (3,877 deals) closed during the 2000-2016 period. Despite the growth of the syndicated loans to LBO market, not only in the first half of the 2000s but also more recently, researchers have barely investigated the driving forces of LBO deals' cost of debt. We contribute to the available literature in several ways. First, to the best of our knowledge, this is the first piece of work that empirically studies how spreads and pricing processes differ between market-based and bank-based financial systems, and considers the period before and during the 2007-2008 financial crisis and the subsequent European sovereign debt crisis.

Second, this work contributes to the banking literature available on loan pricing. By documenting substantial differences in the impact of common pricing variables on spread, we conclude that loans closed in market- vis-à-vis bank-based financial systems are priced in segmented debt markets. In addition, we find that tranching is reflected in loan pricing: the greater the number of tranches per deal, the lower the credit spread, after adjusting for the other micro (at the contract, syndicated structure, and target-firm) and macro-level factors. We thus corroborate the hypothesis of arranging banks structuring deals into several 
tranches, characterized by different risk-return profiles, with the aim of reducing market incompleteness and mitigating asymmetric information costs and, by doing so, reducing loan spreads (Duffie and Rahi 1995; Riddiough 1997; Maskara 2010; Cumming et al. 2020). We also show that targeting firms' characteristics, namely profitability and asset tangibility, affect LBO deals' cost of debt.

Third, our work extends existing literature that debates the relative merits of bank- versus marketbased financial systems by studying empirically if the financial system influences the pricing of LBO loans or if, instead, it is the legal system that matters. We find that loans for LBOs extended to borrowers located in countries with market-based financial systems face higher spreads, even when controlling for investor rights and enforceability of contracts. Results are robust for pre- versus crisis period and when performing a deal-level analysis. We also show that laws - creditor rights - and institutions - efficiency of contractual enforcement -, affect LBO loan spreads especially in market-based financial systems. This is consistent with the importance of both financial system structure and legal system on loan pricing. Overall, the results in this paper and those in previous studies substantially enhance our understanding of how financial systems and countries' institutional characteristics affect spreads and pricing.

Finally, in contrast with the results obtained by Ivashina and Kovner (2011) and Colla et al. (2012), who find a positive linear relationship between spread and maturity, we identify several economic rationales, namely liquidity or cash-flow risk and supply and demand effects, that explain why a robust convex relationship - a "smile" effect - between spread and maturity is found for loans in LBOs. We consider that research exploring the relationship between spread and maturity for other syndicated loan types - project finance, capital structure, fixed asset-based, and general corporate purpose loans -, is an important avenue for future research.

\section{References}

1. Alexandre H, Bouaiss K, Refait-Alexandre C (2014) Banking Relationships and Syndicated Loans during the 2008 Financial Crisis. Journal of Financial Services Research 46, 99-113

2. Axelson U, Strömberg P, Weisbach M (2009) Why Are Buyouts Levered? The Financial Structure of Private Equity Funds. Journal of Structured Finance 64, 1549-1582.

3. Bae K, Goyal V (2009) Creditor Rights, Enforcement, and Bank Loans. Journal of Finance 64, $823-860$ 
4. Bali G, Skinner F (2006) The original maturity of corporate bonds: The influence of credit rating, asset maturity, security, and macroeconomic conditions. Financial Review 41, 187-203

5. Beck T, Levine R (2002) Industry growth and capital allocation: does having a market- or bankbased system matter? Journal of Financial Economics 64, 147-180

6. Benmelech E, Dlugosz J (2009) The alchemy of CDO credit ratings. Journal of Monetary Economics 56, 617-634

7. Berg T, Saunders A, Steffen S (2016) The total cost of corporate borrowing in the loan market: Don't ignore the fees. Journal of Finance 71, 1357-1392

8. Berger A, Udell G (1995) Relationship Lending and Lines of Credit in Small Business Finance. Journal of Business 68, 351-81

9. Berger A, Espinosa-Vega M, Frame S, Miller N (2005) Debt maturity, risk, and asymmetric information. Journal of Finance 60, 2895-2923

10. Berlin M, Loyes J (1988) Bond covenants and delegated monitoring. Journal of Finance 43, 397412

11. Bharath S, Dahiya S, Saunders A, Srinivasan A (2007) So What Do I Get? The Bank's View of Lending Relationships. Journal of Financial Economics 85, 368-419

12. Bharath S, Dahiya S, Saunders A, Srinivasan A (2011) Lending Relationships and Loan Contract Terms. Review of Financial Studies 24, 1141-1203

13. Boot A (2000) Relationship Banking: What Do We Know? Journal of Financial Intermediation 9, 7-25

14. Boubaker S, Cellier A, Rouatbi W (2014) The sources of shareholder gains from going private transactions: The role of controlling shareholders. Journal of Banking and Finance 43, 226-246

15. Boyd J, Prescott E (1986) Financial intermediary coalitions. Journal of Economy Theory 38, 211232

16. Campbell J, Taksler G (2003) Equity volatility and corporate bond yields. Journal of Finance 58, 2321-2349

17. Cao K, Coy J, Nguyen T (2016) The likelihood of management involvement, offer premiums, and target shareholder wealth effects: Evidence from the 2002-2007 LBO wave. Research in International Business and Finance 36, 641-655

18. Cao X, Cumming D, Goh J, Wang X (2019) The impact of investor protection law on global takeovers: LBO vs. non-LBO transactions. Journal of International Financial Markets, Institutions \& Money 59, 1-18

19. Carey M, Nini G (2007) Is the corporate loan market globally integrated? A pricing puzzle. Journal of Finance 62, 2969-3007

20. Caselli S, Gatti S (2005) Structured Finance: Techniques, Products and Market, Springer, Berlin

21. Chakraborty S, Ray T (2006) Bank-based versus market-based financial systems: a growththeoretic analysis. Journal of Monetary Economics 53, 329-350

22. Chemmanur T, Fulghieri P (1994) Reputation, renegotiation, and the choice between bank loans and publicly traded debt. Review of Financial Studies 7, 475-506

23. Chen L, Lesmond D, Wei J (2007) Corporate yield spreads and bond liquidity. Journal of Finance 62, 119-149

24. Colla P, Ippolito F, Wagner H (2012) Leverage and pricing of debt in LBOs. Journal of Corporate Finance 18, 124-137

25. Collin-Dufresne P, Goldstein R, Martin J (2001) The determinants of credit spread changes. Journal of Finance 56, 2177-2207

26. Corielli F, Gatti S, Steffanoni A (2010) Risk shifting through nonfinancial contracts: Effects on loan spreads and capital structure of project finance deals. Journal of Money, Credit and Banking $42,1295-1320$

27. Cumming D, Zambelli S (2010) Illegal buyouts. Journal of Banking and Finance 34, 441-456

28. Cumming D, Lopez-de-Silanes F, McCahery J, Schwienbacher A (2020) Tranching in the syndicated loan market around the world. Journal of International Business Studies 51, 95-120 
29. Dahiya S, Saunders A, Srinivasan A (2003) Financial Distress and Bank Lending Relationships. Journal of Finance 58, 375-99

30. Daniels K, Ramirez G (2008) Information, Credit Risk, Lender Specialization and Loan Pricing: Evidence from the DIP Financing Market. Journal of Financial Services Research 34, 35-59

31. Davydenko S, Franks J (2008) Do bankruptcy codes matter? A study of defaults in France, Germany, and the U.K. Journal of Finance 63, 565-608

32. DeMarzo P (2005). The pooling and tranching of securities: a model of informed intermediation. Review of Financial Studies 18, 1-35

33. DeMarzo P, Duffie D (1999). A liquidity-based model of security design. Econometrica 67, 65-99

34. Demiroglu C, James C (2010) The role of private equity group reputation on LBO financing. Journal of Financial Economics 96, 306-330

35. Demirgüç-Kunt A, Levine R (1999) Financial structures across countries: stylized facts. Mimeograph, World Bank, Washington, DC

36. Demirgüç-Kunt A, Maksimovic V (2002) Funding growth in bank-based and market-based financial systems: evidence from firm-level data. Journal of Financial Economics 65, 337-363

37. Diamond D (1993) Seniority and maturity of debt contracts. Journal of Financial Economics 33, 341368

38. Djankov S, McLiesh C, Shleifer A (2007) Private Credit in 129 Countries. Journal of Financial Economics 12, 77-99

39. Duffie D, Rahi R (1995) Financial market innovation and security design: an introduction. Journal of Economic Theory 65, 1-42

40. Ergungor O (2004) Market- vs. bank-based financial systems: Do rights and regulations really matter? Journal of Banking and Finance 28, 2869-2887

41. Ergungor O (2008) Financial system structure and economic growth: Structure matters. International Review of Economics and Finance 17, 292-305

42. Esty B, Megginson W (2003) Creditor rights, enforcement, and debt ownership structure: Evidence from the global syndicated loan market. Journal of Financial and Quantitative Analysis 38, 37-59

43. Fabozzi F, Davis H, Choudhry M (2006) Introduction to structured finance. Wiley Finance, New Jersey

44. Fama E (1985) What's different about banks? Journal of Monetary Economics 15: 29-39

45. Firestone S, Rezende M (2016) Are Banks' Internal Risk Parameters Consistent? Evidence from Syndicated Loans. Journal of Financial Services Research 50, 211-242

46. Flannery M, Nikolova S, Öztekin Ö (2012) Leverage expectations and bond credit spreads. Journal of Financial and Quantitative Analysis 47, 689-714

47. Gatti S, Kleimeier S, Megginson W, Steffanoni A (2013) Arranger certification in project finance. Financial Management 42, 1-40

48. Heckman J (1979) Sample selection bias as a specification error. Econometrica 47, 153-161

49. Ivashina V (2009) Asymmetric Information Effects on Loan Spreads. Journal of Financial Economics 92, 300-319

50. Ivashina V, Kovner A (2011) The private equity advantage: leveraged buyout firms and relationship banking. The Review of Financial Studies 24, 2462-2498

51. Jensen M (1986) Agency costs of free cash flow, corporate finance, and takeovers. American Economic Review 76, 323-329

52. Kaplan S (1989a) Management Buy-Outs: Evidence on Taxes as a Source of Value. Journal of Finance 44, 611-632

53. Kaplan S (1989b) The Effects of Management Buyouts on Operating Performance and Value. Journal of Financial Economics 24, 217-254

54. Kaplan S, Strömberg P (2009) Leveraged buyouts and private equity. Journal of Economic Perspectives 23, 121-146

55. Kaplan S, Stein J (1993) The evolution of buyout pricing and financial structure in the 1980s. Quarterly Journal of Economics 108, 313-357 
56. Kleimeier S, Megginson W (2000) Are project finance loans different from other syndicated credits? Journal of Applied Corporate Finance 13, 75-87

57. La Porta R, Lopez-de-Silanes F, Shleifer A, Vishny R (1997) Legal determinants of external finance. Journal of Finance 52, 1131-1150

58. La Porta R, Lopez-de-Silanes F, Shleifer A, Vishny R (1998) Law and finance. Journal of Political Economy 106, 1113-1155

59. La Porta R, Lopez-de-Silanes F, Shleifer A, Vishny R (2000) Investor protection and corporate governance. Journal of Financial Economics 58, 3-27

60. Leland H (2007) Financial synergies and the optimal scope of the firm: Implications for mergers, spinoffs, and structured finance. Journal of Finance 62, 765-807

61. Levine R (1997) Financial development and economic growth: views and agenda. Journal of Economic Literature 35, 688-726

62. Levine R (2002) Bank-based or market-based financial systems: which is better? Journal of Financial Intermediation 11, 1-30

63. Lichtenberg F, Siegel D (1990) The Effects of Leveraged Buyouts on Productivity and Related Aspects of Firm Behavior. Journal of Financial Economics 27, 165-194

64. Lim J, Minton B, Weisbach M (2014) Syndicated loan spreads and the composition of the syndicate. Journal of Corporate Finance 111, 45-69

65. Lin C, Ma Y, Malatesta P, Xuan Y (2011) Ownership structure and the cost of corporate borrowing. Journal of Financial Economics 100, 1-23

66. Longstaff F, Mithal S, Neis E (2005) Corporate yield spreads Default risk or liquidity? New evidence from the credit default swap market. Journal of Finance 60, 2213-2253

67. Marques M, Pinto J (2020) A Comparative Analysis of Ex Ante Credit Spreads: Structured Finance versus Straight Debt Finance. Journal of Corporate Finance, forthcoming

68. Maskara P (2010) Economic value in tranching of syndicated loans. Journal of Banking and Finance 34, 946-955

69. Mattes J, Steffen S, Wahrenburg M (2013) Do Information Rents in Loan Spreads Persist over the Business Cycles? Journal of Financial Services Research 43, 175-195

70. Nikoskelainen E, Wright M (2007) The impact of corporate governance mechanisms on value increase in leveraged buyouts. Journal of Corporate Finance 13, 511-537

71. Opler T, Titman S (1993) The Determinants of Leveraged Buyout Activity: Free Cash Flow vs. Financial Distress Costs. Journal of Finance 48, 1985-1999

72. Petersen M, Rajan R (1994) The Benefits of Lending Relationships: Evidence from Small Business Data. Journal of Finance 49, 3-37

73. Pinto J, Santos M (2019) The choice between corporate and structured financing: evidence from new corporate borrowings. European Journal of Finance 26, 1271-1300

74. Qian J, Strahan P (2007) How Laws and Institutions Shape Financial Contracts: The Case of Bank Loans. Journal of Finance 62, 2803-2834

75. Renneboog L, Simons T, Wright M (2007) Why do public firms go private in the UK? The impact of private equity investors, incentive realignment and undervaluation. Journal of Corporate Finance 13, 591-628

76. Riddiough T (1997) Optimal design and governance of asset-backed securities. Journal of Financial Intermediation 6, 121-152

77. Scott J, Smith T (1986) The Effect of the Bankruptcy Reform Act of 1978 on Small Business Loan Pricing. Journal of Financial Economics 16, 119-140

78. Singh M (2017) Private equity deal-making hits 10-year high. Investment Report, Dealogic Research

79. Sorge M, Gadanecz B (2008) The term structure of credit spreads in project finance. International Journal of Finance and Economics 13, 68-81

80. Spamann H (2010) The "Antidirector Rights Index" Revisited, The Review of Financial Studies 23, $467-486$ 
81. Sufi A (2007) Information asymmetry and financing arrangements: Evidence from syndicated loans. Journal of Finance 62, 629-668

82. Titman S, Tompaidis S, Tsyplakov S (2004) Market imperfections, investment flexibility, and default spreads. Journal of Finance 59, 165-205

83. Winton A (1995) Costly state verification and multiple investors: The role of seniority. Review of Financial 


\section{Tables and Figures}

\section{Table 1: Distribution of the full sample of loans in LBOs by year, borrower's nationality, and}

industry

Panel A details the distribution of loans for LBOs across borrower's nationality, while Panel B describes the industrial distribution of tranches. Data are for tranches reported in DealScan with a deal specific purpose code of 'leveraged buy-out' and with spread and tranche amount or deal amount available, closed during the 2000-2016 period. ' includes, among others, the following industries: Newspaper and periodical publishers (3.97\%), 'Paper bag and coated and treated paper' $(1.10 \%)$, 'Pulp and paper mills' $(0.58 \%)$, 'Prefabricated wood building' $(0.40 \%)$, and 'Footwear' $(0.38 \%){ }^{\mathrm{b}}$ includes, among others, 'Software and other prerecorded compact disc, and record reproducing' (3.13\%), 'Other chemical product and preparation' (2.39\%), 'Custom computer programming services' $(1.24 \%)$, 'R\&D in Biotechnology' (1.15\%), 'General management consulting services' (1.02\%).

\section{Panel A: Geographic distribution of loans to LBOs}

\begin{tabular}{|c|c|c|c|c|}
\hline Geographic location of borrower & Number of loans & Number of deals & $\begin{array}{l}\text { Total Value } \\
\text { (\$US million) }\end{array}$ & $\begin{array}{c}\text { Percent of Total } \\
\text { Value }\end{array}$ \\
\hline Europe & 4,953 & 1,258 & 678,665 & $41.74 \%$ \\
\hline Western Europe & 4,885 & 1,240 & 662,784 & $40.76 \%$ \\
\hline U.K. & 1,408 & 365 & 211,125 & $12.98 \%$ \\
\hline Eastern Europe & 68 & 18 & 15,881 & $0.98 \%$ \\
\hline North America & 5,681 & 2,448 & 864,835 & $53.19 \%$ \\
\hline U.S. & 5,527 & 2,384 & 832,637 & $51.21 \%$ \\
\hline Asia & 245 & 99 & 41,495 & $2.55 \%$ \\
\hline Western Asia & 9 & 3 & 2,339 & $0.14 \%$ \\
\hline Eastern Asia & 187 & 76 & 31,909 & $1.96 \%$ \\
\hline China & 19 & 10 & 2,755 & $0.17 \%$ \\
\hline Africa & 8 & 2 & 713 & $0.04 \%$ \\
\hline Australia and Pacific & 216 & 66 & 39,847 & $2.45 \%$ \\
\hline Caribbean & 2 & 1 & 350 & $0.02 \%$ \\
\hline Latin America & 6 & 3 & 167 & $0.01 \%$ \\
\hline Total & $\mathbf{1 1 , 1 1 1}$ & 3,877 & $1,626,071$ & $100.00 \%$ \\
\hline \multicolumn{5}{|c|}{ Panel B: Distribution of loans to LBOs by industrial category of borrower } \\
\hline Industrial Category of Borrower & Number of loans & Number of deals & $\begin{array}{l}\text { Total Value } \\
\text { (\$US million) }\end{array}$ & $\begin{array}{l}\text { Percent of Total } \\
\text { Value }\end{array}$ \\
\hline Commercial and Industrial & 10,411 & 3,626 & $1,461,129$ & $89.86 \%$ \\
\hline Agriculture, Forestry and Fishing & 454 & 186 & 46,920 & $2.89 \%$ \\
\hline Communications & 430 & 140 & 113,364 & $6.97 \%$ \\
\hline Construction/Heavy Engineering & 234 & 69 & 27,245 & $1.68 \%$ \\
\hline Manufacturing & 4,527 & 1,532 & 570,902 & $35.11 \%$ \\
\hline Chemicals, Plastic and Rubber & 872 & 296 & 113,520 & $6.98 \%$ \\
\hline Food and Beverages & 451 & 144 & 42,715 & $2.63 \%$ \\
\hline Machinery and Equipment & 1,535 & 531 & 212,621 & $13.08 \%$ \\
\hline Steel, Aluminum and other Metals & 439 & 152 & 40,071 & $2.46 \%$ \\
\hline Other $^{\text {a }}$ & 1,230 & 409 & 161,976 & $9.96 \%$ \\
\hline Mining and Natural Resources & 46 & 21 & 5,861 & $0.36 \%$ \\
\hline Oil and Gas & 116 & 41 & 22,902 & $1.41 \%$ \\
\hline Real Estate & 195 & 77 & 47,020 & $2.89 \%$ \\
\hline Retail Trade & 865 & 308 & 143,707 & $8.84 \%$ \\
\hline Services & 3,544 & 1,252 & 483,209 & $29.72 \%$ \\
\hline Services - Capital intensive & 1,117 & 366 & 152,414 & $9.37 \%$ \\
\hline Services - Other ${ }^{b}$ & 1,727 & 641 & 255,033 & $15.68 \%$ \\
\hline Wholesale Trade & 700 & 245 & 75,762 & $4.66 \%$ \\
\hline Utilities & 287 & 103 & 92,868 & $5.71 \%$ \\
\hline Transportation & 413 & 148 & 72,073 & $4.43 \%$ \\
\hline Total & 11,111 & 3,877 & $1,626,071$ & $100.00 \%$ \\
\hline
\end{tabular}


Table 2: Definition of variables, sources, and the expected impact on spread

The following characters mean: $-=$ negative impact on spread $\mid+=$ positive impact on spread $\mid \mathrm{I}=$ insignificant impact on spread $\mid$ ? = sign cannot be clearly determined.

\begin{tabular}{|c|c|c|c|}
\hline Variable & Description & Source & $\begin{array}{c}\text { Expected } \\
\text { impact }\end{array}$ \\
\hline \multicolumn{4}{|l|}{ Dependent variables: } \\
\hline Spread & $\begin{array}{l}\text { Loan spread represents the spread paid by the borrower over Libor or Euribor } \\
\text { plus the facility fee (all-in-spread-drawn), converted into dollar-equivalent } \\
\text { spreads when necessary. }\end{array}$ & Dealscan & \\
\hline $\begin{array}{l}\text { Weighted average } \\
\text { spread (WAS) }\end{array}$ & The weighted average between the loan spread and its weight in the deal size. & Dealscan & \\
\hline \multicolumn{4}{|l|}{ Independent variables: } \\
\hline \multicolumn{4}{|c|}{ Contractual characteristics } \\
\hline Maturity & Maturity of loan, in years. & Dealscan & $?$ \\
\hline Number of tranches & Number of loans per deal. & Dealscan & - \\
\hline Tranched & $\begin{array}{l}\text { Dummy equal to } 1 \text { if the loan is tranched into two or more facilities, and } 0 \\
\text { otherwise. }\end{array}$ & Dealscan & - \\
\hline Rated & $\begin{array}{l}\text { Dummy equal to } 1 \text { if the loan has a credit rating from } \mathrm{S} \& \mathrm{P} \text { and/or Moody's, and } 0 \\
\text { otherwise. }\end{array}$ & Dealscan & - \\
\hline Rating & $\begin{array}{l}\text { The } \mathrm{S} \& \mathrm{P} \text { and/or Moody's rating at closing; the rating is converted as follows: } \\
\mathrm{AAA}=\mathrm{Aaa}=1, \mathrm{AA}+=\mathrm{Aa} 1=2 \text {, and so on until } \mathrm{D}=22 \text {. If a tranche has two credit } \\
\text { ratings, we computed the average. }\end{array}$ & Dealscan & + \\
\hline Subordinated & $\begin{array}{l}\text { Dummy equal to } 1 \text { for tranches that are subordinated - classified by Dealscan as } \\
\text { 'Junior Subordinated', 'Mezzanine', 'Senior Subordinated', 'Subordinated'-, and } 0 \\
\text { otherwise. }\end{array}$ & Dealscan & + \\
\hline Log deal size & Natural logarithm of the deal size measured in $\$$ million. & Dealscan & - \\
\hline Currency risk & $\begin{array}{l}\text { Dummy equal to } 1 \text { for loans that are denominated in a currency different from the } \\
\text { currency in the borrower's home country. }\end{array}$ & Dealscan & + \\
\hline Term loan & Dummy equal to 1 if the loan is a term loan and 0 if the loan is a credit line. & Dealscan & + \\
\hline Secured & Dummy equal to 1 if fee information is secured, and 0 otherwise. & Dealscan & - \\
\hline Covenant intensity & $\begin{array}{l}\text { Number of covenants per loan divided by the maximum number of covenants in a } \\
\text { single tranche in our sample. }\end{array}$ & Dealscan & - \\
\hline Fee information & Dummy equal to 1 if fee information is available, and 0 otherwise. & Dealscan & + \\
\hline Upfront fee & $\begin{array}{l}\text { A fee (in bps) paid by the borrower to a bank or a bank syndicate for arranging a } \\
\text { loan. A one-time fee paid at the loan closing date. }\end{array}$ & Dealscan & + \\
\hline Commitment fee & Fees (in bps) that are periodically paid to the bank syndicates. & Dealscan & + \\
\hline \multicolumn{4}{|l|}{ Syndicate structure } \\
\hline Former lender & $\begin{array}{l}\text { Dummy equal to } 1 \text { if the target firm already has an established relationship with a } \\
\text { lead bank during our sampling period, and } 0 \text { otherwise. }\end{array}$ & Dealscan & - \\
\hline Number of lenders & The number of lenders participating in the deal. & Dealscan & - \\
\hline Domestic lead bank & $\begin{array}{l}\text { Dummy equal to } 1 \text { if the bank's syndicate lead bank's (or at least one of the lead } \\
\text { banks) nationality is the same as the deal country, and } 0 \text { otherwise. }\end{array}$ & Dealscan & $?$ \\
\hline Bank reputation & $\begin{array}{l}\text { EMEA mandated arrangers' rank according to Thomson Reuters League Tables. } \\
\text { Ranks range from } 1 \text { (worst) to } 25 \text { (best). }\end{array}$ & $\begin{array}{c}\text { Thomson } \\
\text { Reuters DMI }\end{array}$ & - \\
\hline \multicolumn{4}{|c|}{ Macroeconomic factors } \\
\hline Common-law & $\begin{array}{l}\text { Dummy equal to } 1 \text { if the loan is extended to a borrower located in a country with } \\
\text { a common-law legal regime, and } 0 \text { otherwise. See Appendix A. }\end{array}$ & $\begin{array}{l}\text { Demirgüc-Kunt } \\
\text { and Maksimovic } \\
\text { (2002) }\end{array}$ & + \\
\hline Market-Based & $\begin{array}{l}\text { Dummy equal to } 1 \text { if the loan is extended to a borrower located in a country with } \\
\text { a market-based financial system, and } 0 \text { otherwise. See Appendix A. }\end{array}$ & $\begin{array}{l}\text { Demirgüc-Kunt } \\
\text { and Maksimovic } \\
\text { (2002) }\end{array}$ & + \\
\hline Creditor rights & $\begin{array}{l}\text { Measured using La Porta et al. (1998) indices, revised by Djankov et al. (2007). } \\
\text { We use four creditor rights variables (no automatic stay on assets; secured } \\
\text { creditors first paid; restrictions for going into reorganization; management does } \\
\text { not stay in reorganization) and added up the scores to create an index as in Esty } \\
\text { and Megginson (2003). }\end{array}$ & $\begin{array}{l}\text { LLSV (1998); } \\
\text { Djankov et al. } \\
\quad(2007)\end{array}$ & - \\
\hline Enforcement & $\begin{array}{l}\text { Measured using La Porta et al.'s (1998) indices. We use five enforcement } \\
\text { variables (efficiency of judicial system; rule of law; corruption; risk of } \\
\text { expropriation; risk of contract repudiation) and added up the scores to create an } \\
\text { index. }\end{array}$ & LLSV (1998) & - \\
\hline
\end{tabular}

(Continued) 
Table 2: Definition of variables, sources, and the expected impact on spread (continued)

\begin{tabular}{|c|c|c|c|}
\hline Variable & Description & Source & $\begin{array}{l}\text { Expected } \\
\text { impact }\end{array}$ \\
\hline \multicolumn{4}{|l|}{ Independent variables: } \\
\hline \multicolumn{4}{|l|}{ Macroeconomic factors } \\
\hline Antidirector rights & $\begin{array}{l}\text { Measured using La Porta et al. (1998) indices, revised by Spamann (2010). } \\
\text { Formed by adding one when }(i) \text { the country allows shareholders to mail their } \\
\text { proxy votes; }(\mathrm{ii}) \text { shareholders are not required to deposit their shares prior to the } \\
\text { general shareholders' meeting; ( } \mathrm{iii} \text { ) cumulative voting or proportional } \\
\text { representation of minorities on the board of directors is allowed; }(\mathrm{iv}) \text { an } \\
\text { oppressed minorities mechanism is in place; }(\mathrm{v}) \text { the minimum percentage of } \\
\text { share capital that entitles a shareholder to call for an extraordinary shareholders' } \\
\text { meeting is less than or equal to } 10 \% \text { of the sample median; or ( } v i \text { ) shareholders } \\
\text { have preemptive rights that can only be waived by a shareholder meeting. The } \\
\text { range for the index is from zero to six. }\end{array}$ & $\begin{array}{l}\text { LLSV (1998); } \\
\text { Spamann (2010) }\end{array}$ & + \\
\hline Crisis & $\begin{array}{l}\text { Dummy equal to } 1 \text { if the closing date falls within the } 2008 \text { financial crisis and the } \\
\text { subsequent European sovereign debt crisis period (September 15, 2008- } \\
\text { December } 31,2016 \text { ) and } 0 \text {, otherwise. }\end{array}$ & Authors' & + \\
\hline Log GDP per capita & $\begin{array}{l}\text { Log GDP per capital is the GDP per capita logarithm of the country where the } \\
\text { deal is closed at closing date. }\end{array}$ & World Bank & - \\
\hline Country risk & $\begin{array}{l}\text { S\&P's country credit rating at close. The rating is converted as follows: } \mathrm{AAA}=1 \text {, } \\
\mathrm{AA}+=2 \text {, and so on until } \mathrm{D}=22 \text {. }\end{array}$ & $\mathrm{S} \& \mathrm{P}$ & + \\
\hline $5 y \mathrm{~TB}-3 \mathrm{mTB}$ & $\begin{array}{l}\text { The yield curve slope. Obtained as the difference between the U.S. five-year } \\
\text { Treasury Bond rate and the U.S. 3-month Treasury Bill rate. }\end{array}$ & Datastream & - \\
\hline Volatility & $\begin{array}{l}\text { The Chicago Board Options Exchange Volatility Index (VIX). VIX reflects a } \\
\text { market estimate of future volatility. }\end{array}$ & Datastream & + \\
\hline \multicolumn{4}{|l|}{ Firms' characteristics } \\
\hline Log total assets & Natural log of firm total assets measured in \$US million. & Datastream & - \\
\hline Debt to total assets & The ratio of total debt to total assets. & Datastream & + \\
\hline $\begin{array}{l}\text { Short-tem debt to total } \\
\text { debt }\end{array}$ & $\begin{array}{l}\text { Short-term debt divided by total debt. Short-term debt measures debt maturing } \\
\text { within } 1 \text { year. }\end{array}$ & Datastream & + \\
\hline $\begin{array}{l}\text { Fixed assets to total } \\
\text { assets }\end{array}$ & $\begin{array}{l}\text { The ratio of fixed assets to total assets. Fixed assets include property, plant and } \\
\text { equipment. }\end{array}$ & Datastream & - \\
\hline Market to book ratio & $\begin{array}{l}\text { The sum of book value of liabilities and market value of equity divided by the } \\
\text { book value of assets. }\end{array}$ & Datastream & - \\
\hline Return on assets & $\begin{array}{l}\text { Net income before preferred dividends minus preferred dividend requirement, } \\
\text { divided by total assets }\end{array}$ & Datastream & - \\
\hline Free cash flow to assets & The ratio of free cash flow to total assets. & Datastream & - \\
\hline Z-score & $\begin{array}{l}\text { Altman's (1993) Z-score, calculated as Z=1.2 (Working Capital/Total Assets) }+ \\
1.4 \text { (Retained Earnings/Total Assets) }+3.3 \text { (Earnings Before Interest and } \\
\text { Taxes/Total Assets) + 0.6 (Market Value of Equity/Book Value of Liabilities) + } \\
0.999 \text { (Net Sales/Total Assets). }\end{array}$ & Datastream & - \\
\hline
\end{tabular}


Table 3: Regression analyses of the determinants of tranche spreads

This table presents the results of GMM regressions on spreads (AIS drawn in bps) for loans extended to LBOs. Models [1] and [2] reflect the full sample. Models [3] and [4] focus on sub-samples created according to whether the loan is

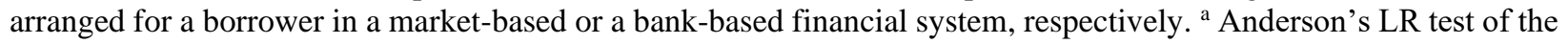
null hypothesis that our instruments - if the loan is tranched and the tranche size - and endogenous variables are not correlated. ${ }^{\mathrm{b}}$ Hansen's $J$-test for overidentification restrictions. For each independent variable, the first row reports the estimated coefficient and the second row reports the $p$-value. Standard errors are heteroskedasticity robust and clustered at the deal-year level. For a definition of the variables, see Table 2.

\begin{tabular}{|c|c|c|c|c|}
\hline Dependent variable: & All Loans & All Loans & Market-Based & Bank-based \\
\hline Spread (bps) & [1] & [2] & [3] & [4] \\
\hline \multicolumn{5}{|l|}{ Independent variables: } \\
\hline \multicolumn{5}{|l|}{ Core variables } \\
\hline Market-Based & $\begin{array}{l}109.31 \\
(0.000)\end{array}$ & $\begin{array}{l}163.96^{\text {*k* }} \\
(0.000)\end{array}$ & & \\
\hline Creditor rights & & $\begin{array}{l}-36.51 \\
(0.000)\end{array}$ & $\begin{array}{l}-56.11^{\text {*k*k }} \\
(0.000)\end{array}$ & $\begin{array}{r}4.75 \\
(0.167) \\
\end{array}$ \\
\hline Enforcement & & $\begin{array}{r}-3.29 \\
(0.161)\end{array}$ & $\begin{array}{l}-19.46^{\text {*k* }} \\
(0.000)\end{array}$ & $\begin{array}{r}-4.99 \\
(0.159)\end{array}$ \\
\hline Antidirector rights & & $\begin{array}{l}-10.53^{\text {*k* }} \\
(0.000)\end{array}$ & $\begin{array}{r}1.69 \\
(0.473)\end{array}$ & $\begin{array}{r}-6.48 \\
(0.261)\end{array}$ \\
\hline Crisis & $\begin{array}{l}183.82^{* * *} \\
(0.000)\end{array}$ & $\begin{array}{l}165.71^{* * *} \\
(0.000)\end{array}$ & $\begin{array}{l}149.14^{\text {*** }} \\
(0.000)\end{array}$ & $\begin{array}{l}209.72^{\text {**** }} \\
(0.000)\end{array}$ \\
\hline Number of tranches & $\begin{array}{l}-12.53^{\text {*k*k }} \\
(0.000)\end{array}$ & $\begin{array}{l}-11.35^{\text {*k* }} \\
(0.001)^{3 *}\end{array}$ & $(0.012)$ & $(0.011)^{* *}$ \\
\hline Maturity & $\begin{array}{l}76.07^{\text {*** }} \\
(0.000)^{-}\end{array}$ & $\begin{array}{l}100.25^{\text {*** }} \\
(0.000)\end{array}$ & $\begin{array}{l}76.95^{\text {*k* }} \\
(0.000)\end{array}$ & $\begin{array}{l}111.69^{\text {*** }} \\
(0.001)\end{array}$ \\
\hline \multicolumn{5}{|l|}{ Contractual controls } \\
\hline Rated & $\begin{array}{l}-79.05^{* * *} \\
(0.006)\end{array}$ & $\begin{array}{l}-82.08^{* *} \\
(0.013)\end{array}$ & $\begin{array}{l}-122.86^{\text {*** }} \\
(0.000)\end{array}$ & $\begin{array}{r}87.55 \\
(0.181)\end{array}$ \\
\hline Rated*rating & $\begin{array}{l}7.72^{* * *} \\
(0.000)\end{array}$ & $\begin{array}{l}5.96^{* * *} \\
(0.007)\end{array}$ & $\begin{array}{l}8.00^{\text {*** }} \\
(0.000)\end{array}$ & $\begin{array}{r}-5.53 \\
(0.192) \\
\end{array}$ \\
\hline Subordinated & $\begin{array}{l}249.55^{\text {*k*k }} \\
(0.000)\end{array}$ & $\begin{array}{l}224.70^{\text {*** }} \\
(0.000)\end{array}$ & $\begin{array}{l}248.07^{\text {*k* }} \\
(0.000)\end{array}$ & $\begin{array}{l}197.14^{\text {** }} \\
(0.016)\end{array}$ \\
\hline Log deal size & $\begin{array}{l}-17.57^{* 3 * k} \\
(0.000)\end{array}$ & $\begin{array}{l}-11.83^{* * *} \\
(0.000)\end{array}$ & $\begin{array}{l}-17.81^{\text {Nk* }} \\
(0.000)\end{array}$ & $\begin{array}{r}-3.22 \\
(0.605) \\
\end{array}$ \\
\hline Currency risk & $\begin{array}{r}-9.29 \\
(0.211) \\
\end{array}$ & $\begin{array}{r}3.13 \\
(0.725) \\
\end{array}$ & $\begin{array}{r}2.49 \\
(0.771)\end{array}$ & $\begin{array}{r}50.32 \\
(0.016)\end{array}$ \\
\hline Term loan & $\begin{array}{r}4.15 \\
(0.677)\end{array}$ & $\begin{array}{r}-9.47 \\
(0.456)\end{array}$ & $\begin{array}{r}11.23 \\
(0.317)\end{array}$ & $\begin{array}{c}-22.60 \\
(0.206)\end{array}$ \\
\hline Fee information & $\begin{array}{r}-9.72 \\
(0.168) \\
\end{array}$ & $\begin{array}{r}-13.25 \\
(0.103) \\
\end{array}$ & $\begin{array}{r}-4.67 \\
(0.531) \\
\end{array}$ & $\begin{array}{l}27.76^{* *} \\
(0.047) \\
\end{array}$ \\
\hline \multicolumn{5}{|l|}{ Syndicate structure } \\
\hline Former lender & $\begin{array}{l}-20.79^{* *} \\
(0.011)^{2}\end{array}$ & $\begin{array}{l}-29.97^{\text {*** }} \\
(0.001)\end{array}$ & $\begin{array}{r}-12.77 \\
(0.109) \\
\end{array}$ & $\begin{array}{l}-28.33^{*} \\
(0.055)\end{array}$ \\
\hline Number of lenders & $\begin{array}{r}0.30 \\
(0.612) \\
\end{array}$ & $\begin{array}{r}0.19 \\
(0.774) \\
\end{array}$ & $\begin{array}{r}-0.88 \\
(0.075)\end{array}$ & $\begin{array}{l}-1.36 \\
(0.024)\end{array}$ \\
\hline Domestic lead bank & $\begin{array}{c}13.41^{* *} \\
(0.033)\end{array}$ & $\begin{array}{r}10.31 \\
(0.131)\end{array}$ & $\begin{array}{r}2.11 \\
(0.730)\end{array}$ & $\begin{array}{r}9.34 \\
(0.403)\end{array}$ \\
\hline Bank reputation & $\begin{array}{l}2.09^{\text {*** }} \\
(0.000)\end{array}$ & $\begin{array}{l}2.30 \\
(0.000)\end{array}$ & $(0.000)$ & $\begin{array}{r}1.02 \\
(0.141)\end{array}$ \\
\hline \multicolumn{5}{|l|}{ Macroeconomic controls } \\
\hline Log GDP per capita & $\begin{array}{l}346.21^{* * * k} \\
(0.004)\end{array}$ & $\begin{array}{l}422.27^{* *} \\
(0.011)\end{array}$ & $\begin{array}{l}885.91^{\text {*** }} \\
(0.000)\end{array}$ & $\begin{array}{r}61.32 \\
(0.816) \\
\end{array}$ \\
\hline Country risk & $\begin{array}{l}8.62^{* * *} \\
(0.003)^{*}\end{array}$ & $\begin{array}{l}12.18^{* * *} \\
(0.001)^{*}\end{array}$ & $\begin{array}{r}-4.87 \\
(0.655)\end{array}$ & $\begin{array}{r}2.55 \\
(0.544)\end{array}$ \\
\hline TB5y-TB3M & $\begin{array}{l}0.12^{* * *} \\
(0.000)\end{array}$ & $\begin{array}{l}0.19^{\text {*** }} \\
(0.000)^{2}\end{array}$ & $\begin{array}{l}0.19^{\text {k** }} \\
(0.000)^{-}\end{array}$ & $\begin{array}{r}0.09 \\
(0.130) \\
\end{array}$ \\
\hline Volatility & $\begin{array}{r}0.09 \\
(0.804) \\
\end{array}$ & $\begin{array}{r}0.53 \\
(0.195) \\
\end{array}$ & $\begin{array}{l}1.95^{\text {*小* }} \\
(0.000)\end{array}$ & $\begin{array}{r}1.93 \\
(0.003)\end{array}$ \\
\hline Industry fixed effects & Yes & Yes & Yes & Yes \\
\hline Number of observations & 11,111 & 11,111 & 7,944 & 3,167 \\
\hline Adjusted $\mathrm{R}^{2}$ & 0.86 & 0.83 & 0.89 & 0.71 \\
\hline $\begin{array}{l}\text { Anderson's LR statistic a } \\
p \text {-value }\end{array}$ & $\begin{array}{r}15.74 \\
(0.000)\end{array}$ & $\begin{array}{r}12.94 \\
(0.000)\end{array}$ & $\begin{array}{r}13.90 \\
(0.000)\end{array}$ & $\begin{array}{r}3.37 \\
(0.035)\end{array}$ \\
\hline $\begin{array}{l}\text { Hansen's J-statistic }{ }^{\mathrm{b}} \\
p \text {-value }\end{array}$ & $\begin{array}{r}0.02 \\
(0.897) \\
\end{array}$ & $\begin{array}{r}2.46 \\
(0.117) \\
\end{array}$ & $\begin{array}{r}4.45 \\
(0.349) \\
\end{array}$ & $\begin{array}{r}0.28 \\
(0.596)\end{array}$ \\
\hline
\end{tabular}

$* p$-value $<0.10, * * p$-value $<0.05, * * * p$-value $<0.01$. 
Table 4: Regression analyses of the impact of the financial crisis

This table presents the results of GMM regressions on spreads (AIS drawn in bps) for loans extended to LBOs. Models [2], [3], and [4] in Table 3 are re-estimated including the interaction terms between the crisis dummy variable - equal to 1 if the closing date falls within the 2008 financial crisis and the subsequent European sovereign debt crisis period (September 15, 2008 - December 31, 2016) and 0, otherwise - and core variables. ${ }^{a}$ Anderson's LR test of the null hypothesis that our instruments - if the loan is tranched and the tranche size - and endogenous variables are not correlated. ${ }^{b}$ Hansen's $J$-test for overidentification restrictions. For each independent variable, the first row reports the estimated coefficient and the second row reports the $p$-value. Standard errors are heteroskedasticity robust and clustered at the deal-year level. For a definition of the variables, see Table 2.

\begin{tabular}{|c|c|c|c|}
\hline Dependent variable: & All Loans & Market-Based & Bank-based \\
\hline Spread (bps) & [5] & [6] & [7] \\
\hline \multicolumn{4}{|l|}{ Independent variables: } \\
\hline \multicolumn{4}{|l|}{ Core variables } \\
\hline Market-Based & $\begin{array}{l}176.01^{\text {**** }} \\
(0.000)\end{array}$ & & \\
\hline Market-Based*Crisis & $\begin{array}{l}-81.45^{\text {*** }} \\
(0.005)\end{array}$ & & \\
\hline Creditor rights & $\begin{array}{l}-43.53^{* * * *} \\
(0.000)\end{array}$ & $\begin{array}{l}-68.11^{\text {**** }} \\
(0.000)\end{array}$ & $\begin{array}{r}0.59 \\
(0.885) \\
\end{array}$ \\
\hline Creditor rights*Crisis & $\begin{array}{l}37.97^{* .2 .4} \\
(0.000)\end{array}$ & $\begin{array}{r}47.44^{* 2 * 4} \\
(0.001)\end{array}$ & $\begin{array}{r}7.64 \\
(0.370) \\
\end{array}$ \\
\hline Enforcement & $\begin{array}{c}-4.70 * \\
(0.089)\end{array}$ & $\begin{array}{l}-25.33^{* * * *} \\
(0.000)\end{array}$ & $\begin{array}{r}-6.07 \\
(0.186) \\
\end{array}$ \\
\hline Enforcement*Crisis & $\begin{array}{l}13.03^{* * * *} \\
(0.005)\end{array}$ & $\begin{array}{c}10.48^{* *} \\
(0.033) \\
\end{array}$ & $\begin{array}{l}15.47^{* *} \\
(0.035) \\
\end{array}$ \\
\hline Antidirector rights & $\begin{array}{c}-9.73^{* * * *} \\
(0.000)\end{array}$ & $\begin{array}{r}0.52 \\
(0.847) \\
\end{array}$ & $\begin{array}{r}-6.86 \\
(0.364) \\
\end{array}$ \\
\hline Antidirector rights*Crisis & $\begin{array}{r}-12.22 \\
(0.133) \\
\end{array}$ & $\begin{array}{r}-10.60 \\
(0.451) \\
\end{array}$ & $\begin{array}{r}-7.07 \\
(0.588) \\
\end{array}$ \\
\hline Crisis & $\begin{array}{r}56.18 \\
(0.757) \\
\end{array}$ & $\begin{array}{r}-43.55 \\
(0.832) \\
\end{array}$ & $\begin{array}{r}235.70 \\
(0.268) \\
\end{array}$ \\
\hline Number of tranches & $\begin{array}{l}-14.33^{* * *} \\
(0.001)\end{array}$ & $\begin{array}{l}-7.19^{* *} \\
(0.011)\end{array}$ & $\begin{array}{l}-5.43^{* *} \\
(0.021)\end{array}$ \\
\hline Number of tranches*Crisis & $\begin{array}{c}12.50 \\
(0.013) \\
\end{array}$ & $\begin{array}{r}7.57 \\
(0.131) \\
\end{array}$ & $\begin{array}{r}5.97 \\
(0.453) \\
\end{array}$ \\
\hline Maturity & $\begin{array}{l}109.64^{* * * *} \\
(0.000)\end{array}$ & $\begin{array}{l}92.28 \text { **** } \\
(0.000)\end{array}$ & $\begin{array}{l}131.94^{* * * *} \\
(0.006)\end{array}$ \\
\hline Maturity*Crisis & $\begin{array}{r}-89.86 \\
(0.000) \\
\end{array}$ & $\begin{array}{l}-67.82^{* 2 *} \\
(0.001)\end{array}$ & $\begin{array}{l}-116.53 \\
(0.013)\end{array}$ \\
\hline Contractual controls & Yes & Yes & Yes \\
\hline Syndicate structure & Yes & Yes & Yes \\
\hline Macroeconomic controls & Yes & Yes & Yes \\
\hline Industry fixed effects & Yes & Yes & Yes \\
\hline Number of observations & 11,111 & 7,944 & 3,167 \\
\hline Adjusted $\mathrm{R}^{2}$ & 0.83 & 0.88 & 0.65 \\
\hline Anderson's LR statistic ${ }^{a}$ & 11.96 & 10.33 & 2.71 \\
\hline$p$-value & $(0.000)$ & $(0.000)$ & $(0.067)$ \\
\hline Hansen's J-statistic $^{\mathrm{b}}$ & 0.85 & 1.33 & 0.01 \\
\hline$p$-value & $(0.357)$ & $(0.249)$ & $(0.995)$ \\
\hline
\end{tabular}

$* p$-value $<0.10, * * p$-value $<0.05, * * * p$-value $<0.01$. 
Table 5: Regression analyses of the term structure of spreads

This table presents the results of GMM regressions on spreads (AIS drawn in bps) for loans extended to LBOs. Models in Table 4 are re-estimated by adding the logarithmic of maturity and the interaction term between this variable and

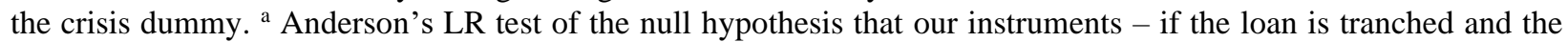
tranche size - and endogenous variables are not correlated. ${ }^{\mathrm{b}}$ Hansen's $J$-test for overidentification restrictions. For each independent variable, the first row reports the estimated coefficient and the second row reports the $p$-value. Standard errors are heteroskedasticity robust and clustered at the deal-year level. For a definition of the variables, see Table 2.

\begin{tabular}{|c|c|c|c|}
\hline Dependent variable: & All Loans & Market-Based & Bank-based \\
\hline Spread (bps) & {$[8]$} & [9] & [10] \\
\hline \multicolumn{4}{|l|}{ Independent variables: } \\
\hline \multicolumn{4}{|l|}{ Core variables } \\
\hline Market-Based & $\begin{array}{l}209.94^{* * * *} \\
(0.000)\end{array}$ & & \\
\hline Market-Based $*$ Crisis & $\begin{array}{l}-117.08^{* * * *} \\
(0.000)\end{array}$ & & \\
\hline Creditor rights & $\begin{array}{l}-50.01^{\text {**** }} \\
(0.000)\end{array}$ & $\begin{array}{l}-63.89^{\text {**** }} \\
(0.000)\end{array}$ & $\begin{array}{r}5.78 \\
(0.430)\end{array}$ \\
\hline Creditor rights*Crisis & $\begin{array}{l}48.83^{* * * *} \\
(0.000) \\
\end{array}$ & $\begin{array}{l}43.49^{* * * *} \\
(0.003) \\
\end{array}$ & $\begin{array}{r}2.95 \\
(0.695) \\
\end{array}$ \\
\hline Enforcement & $\begin{array}{r}4.000^{* * * *} \\
(0.008)\end{array}$ & $\begin{array}{l}-22.59^{* * * *} \\
(0.000)\end{array}$ & $\begin{array}{l}4.85^{\text {**** }} \\
(0.003)\end{array}$ \\
\hline Enforcement*Crisis & $\begin{array}{c}5.86{ }^{*} \\
(0.063) \\
\end{array}$ & $\begin{array}{c}8.23^{* * *} \\
(0.044) \\
\end{array}$ & $\begin{array}{c}6.42^{*} \\
(0.052)\end{array}$ \\
\hline Antidirector rights & $\begin{array}{l}-11.07^{* * * *} \\
(0.000)\end{array}$ & $\begin{array}{r}-1.60 \\
(0.390)\end{array}$ & $\begin{array}{r}7.00 \\
(0.900)\end{array}$ \\
\hline Antidirector rights*Crisis & $\begin{array}{l}-14.06^{* *} \\
(0.049)\end{array}$ & $\begin{array}{c}-5.42^{*} \\
(0.067)\end{array}$ & $\begin{array}{r}-24.72 \\
(0.130)\end{array}$ \\
\hline Crisis & $\begin{array}{r}-244.36 \\
(0.110)\end{array}$ & $\begin{array}{r}-498.78 \\
(0.590)\end{array}$ & $\begin{array}{r}31.66 \\
(0.830)\end{array}$ \\
\hline Number of tranches & $\begin{array}{l}-14.02^{* * *} \\
(0.000)\end{array}$ & ${ }^{-2.92^{* *}}$ & $\begin{array}{c}-5.311^{*} \\
(0.069)\end{array}$ \\
\hline Number of tranches*Crisis & $\begin{array}{c}6.17^{* * * * *} \\
(0.000)\end{array}$ & $\begin{array}{r}8.94 \\
(0.630)\end{array}$ & $\begin{array}{r}3.90 \\
(0.549)\end{array}$ \\
\hline Maturity & $\begin{array}{l}297.49^{\text {**** }} \\
(0.000)\end{array}$ & $\begin{array}{l}201.611^{* * * *} \\
(0.003)^{4}\end{array}$ & $\begin{array}{l}263.53^{\text {**** }} \\
(0.000)\end{array}$ \\
\hline Maturity*Crisis & $\begin{array}{l}-252.59^{* * * *} \\
(0.000)\end{array}$ & $\begin{array}{l}-138.26^{* *} \\
(0.017)\end{array}$ & $\begin{array}{l}-247.67^{\text {**** }}(0.000)\end{array}$ \\
\hline Log maturity & $\begin{array}{c}-1027.69^{* * * *} \\
(0.000)\end{array}$ & $\begin{array}{l}-725.92^{* * * *} \\
(0.003)\end{array}$ & $\begin{array}{l}-854.66^{* * * *} \\
(0.000)\end{array}$ \\
\hline Log maturity*Crisis & $\begin{array}{l}940.16^{* * * *} \\
(0.000)\end{array}$ & $\begin{array}{l}560.60^{\text {*** }} \\
(0.012)\end{array}$ & $\begin{array}{l}765.26^{* * * *} \\
(0.000)\end{array}$ \\
\hline Contractual controls & Yes & Yes & Yes \\
\hline Syndicate structure & Yes & Yes & Yes \\
\hline Macroeconomic controls & Yes & Yes & Yes \\
\hline Industry fixed effects & Yes & Yes & No \\
\hline Number of observations & 11,111 & 7,944 & 3,167 \\
\hline Adjusted $\mathrm{R}^{2}$ & 0.82 & 0.90 & 0.81 \\
\hline Anderson's LR statistic ${ }^{a}$ & 9.85 & 5.96 & 8.72 \\
\hline$p$-value & $(0.000)$ & $(0.003)$ & $(0.000)$ \\
\hline Hansen's J-statistic ${ }^{\mathrm{b}}$ & 3.88 & 4.51 & 1.02 \\
\hline$p$-value & $(0.167)$ & $(0.124)$ & $(0.314)$ \\
\hline
\end{tabular}

$* p$-value $<0.10, * * p$-value $<0.05, * * * p$-value $<0.01$. 


\section{Table 6: The impact of acquired firms' characteristics on spreads}

This table presents the results of GMM regressions on spreads (AIS drawn in bps) for loans extended to LBOs. Models [2], [3], and [4] in Table 3 are re-estimated by adding acquired firms' characteristics. ${ }^{a}$ Anderson's LR test of the null hypothesis that our instruments - if the loan is tranched and the tranche size - and endogenous variables are not correlated. ${ }^{\mathrm{b}}$ Hansen's $J$-test for overidentification restrictions. For each independent variable, the first row reports the estimated coefficient and the second row reports the $p$-value. Standard errors are heteroskedasticity robust and clustered at the deal-year level. For a definition of the variables, see Table 2.

\begin{tabular}{|c|c|c|c|}
\hline Dependent variable: & All Loans & Market-Based & Bank-Based \\
\hline Spread (bps) & [11] & [12] & [13] \\
\hline \multicolumn{4}{|l|}{ Independent variables: } \\
\hline \multicolumn{4}{|l|}{ Core variables } \\
\hline Market-Based & $\begin{array}{l}143.96^{\text {**** }} \\
(0.000)\end{array}$ & & \\
\hline Creditor rights & $\begin{array}{l}-34.44 \\
(0.000)\end{array}$ & $\begin{array}{l}-49.14^{\text {***k }} \\
(0.001)\end{array}$ & $\begin{array}{r}-2.02 \\
(0.759)\end{array}$ \\
\hline Enforcement & $\begin{array}{r}-0.81 \\
(0.820)\end{array}$ & $\begin{array}{l}-11.02^{* * *} \\
(0.012)^{2}\end{array}$ & $\begin{array}{r}-3.42 \\
(0.636)\end{array}$ \\
\hline Antidirector rights & $\begin{array}{l}-8.19^{*} \\
(0.058)\end{array}$ & $\begin{array}{r}2.87 \\
(0.439)\end{array}$ & $\begin{array}{l}-12.59 \\
(0.245)\end{array}$ \\
\hline Crisis & $\begin{array}{l}185.27^{\text {*** }} \\
(0.000)^{2}\end{array}$ & $\begin{array}{l}177.08^{* * *} \\
(0.000)^{3 *}\end{array}$ & $\begin{array}{l}134.93^{* * * k} \\
(0.001)^{* * *}\end{array}$ \\
\hline Number of tranches & $\begin{array}{l}-2.04^{*} \\
(0.051)\end{array}$ & $\begin{array}{c}-4.14^{*} \\
(0.066)\end{array}$ & $\begin{array}{l}-2.73^{* *} \\
(0.049)\end{array}$ \\
\hline Maturity & $\begin{array}{l}79.10^{\text {** }} \\
(0.020)\end{array}$ & $\begin{array}{r}50.62 \\
(0.126)\end{array}$ & $\begin{array}{l}63.10^{* * *} \\
(0.049)\end{array}$ \\
\hline \multicolumn{4}{|l|}{ Firms' characteristics } \\
\hline Log total assets & $\begin{array}{r}2.30 \\
(0.532) \\
\end{array}$ & $\begin{array}{r}3.10 \\
(0.48) \\
\end{array}$ & $\begin{array}{r}-0.54 \\
(0.92) \\
\end{array}$ \\
\hline Debt to total assets & $\begin{array}{r}5.44 \\
(0.661)\end{array}$ & $\begin{array}{r}10.99 \\
(0.382)\end{array}$ & $\begin{array}{r}-31.01 \\
(0.463)\end{array}$ \\
\hline Fixed assets to total assets & $\begin{array}{r}-7.55 \\
(0.727) \\
\end{array}$ & $\begin{array}{r}11.52 \\
(0.650) \\
\end{array}$ & $\begin{array}{l}-121.96^{* * *} \\
(0.023)\end{array}$ \\
\hline Market to book & $\begin{array}{r}0.71 \\
(0.853) \\
\end{array}$ & $\begin{array}{r}-1.11 \\
(0.826) \\
\end{array}$ & $\begin{array}{r}4.05 \\
(0.550) \\
\end{array}$ \\
\hline Return on assets & $\begin{array}{l}-52.09^{* * *} \\
(0.026)\end{array}$ & $\begin{array}{l}-38.33^{* * *} \\
(0.047)\end{array}$ & $\begin{array}{l}-64.56 \\
(0.058)\end{array}$ \\
\hline FCF to total assets & $\begin{array}{r}32.66 \\
(0.333) \\
\end{array}$ & $\begin{array}{r}45.23 \\
(0.192)\end{array}$ & $\begin{array}{r}-5.35 \\
(0.954)\end{array}$ \\
\hline Contractual controls & Yes & Yes & Yes \\
\hline Syndicate structure & Yes & Yes & Yes \\
\hline Macroeconomic controls & Yes & Yes & Yes \\
\hline Industry fixed effects & Yes & Yes & No \\
\hline Number of observations & 2,141 & 1,628 & 513 \\
\hline Adjusted $\mathrm{R}^{2}$ & 0.84 & 0.89 & 0.87 \\
\hline Anderson's LR statistic ${ }^{a}$ & 2.46 & 2.74 & 2.35 \\
\hline$p$-value & $(0.086)$ & $(0.063)$ & $(0.097)$ \\
\hline Hansen's J-statistic ${ }^{b}$ & 10.37 & 14.29 & 0.27 \\
\hline$p$-value & $(0.001)$ & $(0.000)$ & $(0.605)$ \\
\hline
\end{tabular}

$* p$-value $<0.10, * * p$-value $<0.05, * * * p$-value $<0.01$. 
Table 7: A deal-level analysis

This table presents the results of GMM regressions on weighted average spreads (WAS), computed as the weighted average between the tranche spread (AIS drawn in bps) and its weight in the deal size, for loans extended to LBOs. ${ }^{\text {a }}$ Anderson's LR test of the null hypothesis that our instruments - if the deal is tranched and the deal active year - and endogenous variables are not correlated. ${ }^{\mathrm{b}}$ Hansen's $J$-test for overidentification restrictions. For each independent variable, the first row reports the estimated coefficient and the second row reports the $p$-value. Standard errors are heteroskedasticity robust and clustered at the firm-year level. For a definition of the variables, see Table 2.

\section{Dependent variable:}

\begin{tabular}{|c|c|c|c|c|c|}
\hline 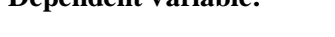 & All Loans & Market-Based & Bank-Based & All Loans & Market-Based \\
\hline WAS (bps) & [14] & [15] & [16] & [17] & [18] \\
\hline \multicolumn{6}{|l|}{ Independent variables: } \\
\hline \multicolumn{6}{|l|}{ Core variables } \\
\hline Market-Based & $\begin{array}{l}79.28 \\
(0.000)\end{array}$ & & & $\begin{array}{l}60.11^{* * *} \\
(0.011)\end{array}$ & \\
\hline Creditor rights & $\begin{array}{l}-13.61 \\
(0.000)\end{array}$ & $\begin{array}{l}-21.52^{* * * *} \\
(0.000)\end{array}$ & $\begin{array}{r}6.29 \\
(0.880) \\
\end{array}$ & $\begin{array}{r}-7.15 \\
(0.437) \\
\end{array}$ & $\begin{array}{l}-10.55^{* *} \\
(0.042)\end{array}$ \\
\hline Enforcement & $\begin{array}{r}1.49 \\
(0.414) \\
\end{array}$ & $\begin{array}{c}-7.99^{*} \\
(0.071) \\
\end{array}$ & $\begin{array}{r}1.16 \\
(0.696)\end{array}$ & $\begin{array}{r}-2.29 \\
(0.619)\end{array}$ & $\begin{array}{l}-23.06^{* * *} \\
(0.011) \\
\end{array}$ \\
\hline Antidirector rights & $\begin{array}{l}-6.28 \\
(0.001)\end{array}$ & $\begin{array}{r}-1.62 \\
(0.490) \\
\end{array}$ & $\begin{array}{r}-3.63 \\
(0.435) \\
\end{array}$ & $\begin{array}{r}-7.93 \\
(0.201) \\
\end{array}$ & $\begin{array}{c}5.76 \\
(0.316) \\
\end{array}$ \\
\hline Crisis & $\begin{array}{l}109.19^{* * * *} \\
(0.000)\end{array}$ & $\begin{array}{l}104.22^{* * *} \\
(0.000)\end{array}$ & $\begin{array}{l}126.59^{* * * *} \\
(0.000)\end{array}$ & $\begin{array}{l}131.04^{* * *} \\
(0.000)\end{array}$ & $\begin{array}{l}123.67^{* * *} \\
(0.000)\end{array}$ \\
\hline Number of tranches & $\begin{array}{l}13.85^{\text {क*** }} \\
(0.000)\end{array}$ & $\begin{array}{l}17.16^{\text {*** }} \\
(0.000)\end{array}$ & $\begin{array}{r}8.23 \\
(0.137) \\
\end{array}$ & $\begin{array}{l}13.70^{\text {**** }} \\
\left(0.00^{\prime} 2\right)\end{array}$ & $\begin{array}{l}17.00^{\text {*** }} \\
(0.001)^{-10}\end{array}$ \\
\hline WAM & $\begin{array}{r}2.94 \\
(0.871) \\
\end{array}$ & $\begin{array}{r}1.26 \\
(0.943) \\
\end{array}$ & $\begin{array}{r}32.40 \\
(0.354) \\
\end{array}$ & $\begin{array}{r}5.10 \\
(0.853) \\
\end{array}$ & $\begin{array}{l}-12.05 \\
(0.706) \\
\end{array}$ \\
\hline \multicolumn{6}{|l|}{ Contractual controls } \\
\hline Log deal size & $\begin{array}{l}-7.26 \\
(0.009)\end{array}$ & $\begin{array}{l}-12.68 \\
(0.000)\end{array}$ & $\begin{array}{l}12.58 \\
(0.035)\end{array}$ & $\begin{array}{r}-8.23 \\
(0.157) \\
\end{array}$ & $\begin{array}{r}-9.07 \\
(0.147) \\
\end{array}$ \\
\hline Currency risk & $\begin{array}{c}19.122^{*} \\
(0.055)\end{array}$ & $\begin{array}{l}28.34^{* * *} \\
(0.006)\end{array}$ & $\begin{array}{l}63.01 \\
(0.050)\end{array}$ & $\begin{array}{r}28.33 \\
(0.332) \\
\end{array}$ & $\begin{array}{r}16.59 \\
(0.496) \\
\end{array}$ \\
\hline \multicolumn{6}{|l|}{ Syndicate structure } \\
\hline Former lender & $\begin{array}{r}7.64 \\
(0.399) \\
\end{array}$ & $\begin{array}{r}1.28 \\
(0.886) \\
* * * 4\end{array}$ & $\begin{array}{r}27.30 \\
(0.149) \\
\end{array}$ & $\begin{array}{c}0.87 \\
(0.952) \\
\end{array}$ & $\begin{array}{r}-0.57 \\
(0.972) \\
\end{array}$ \\
\hline Number of lenders & $(0.000)$ & $\begin{array}{l}-2.95^{* * * *} \\
(0.000) \\
\end{array}$ & $\begin{array}{r}-1.26 \\
(0.139) \\
\end{array}$ & $\begin{array}{l}-2.29^{\text {**** }} \\
(0.002) \\
\end{array}$ & $\begin{array}{l}-2.53^{* *} \\
(0.019) \\
\end{array}$ \\
\hline Domestic lead bank & $\begin{array}{l}-16.95^{* * * *} \\
(0.004)\end{array}$ & $\begin{array}{l}-11.99^{*} \\
(0.057)\end{array}$ & $\begin{array}{r}-14.15 \\
(0.187)\end{array}$ & $\begin{array}{l}-23.41^{*} \\
(0.087)\end{array}$ & $\begin{array}{l}-38.13^{* * *} \\
(0.004)\end{array}$ \\
\hline Bank reputation & $\begin{array}{l}1.45^{* * * *} \\
(0.000)\end{array}$ & $\begin{array}{c}1.34^{* * *} \\
(0.000)\end{array}$ & $\begin{array}{r}-0.10 \\
(0.871) \\
\end{array}$ & ${ }^{1.622^{* *}}$ & $\begin{array}{l}2.15^{\text {**** }} \\
(0.001)\end{array}$ \\
\hline \multicolumn{6}{|l|}{ Macroeconomic controls } \\
\hline Log GDP per capita & $\begin{array}{l}565.06^{\text {**** }} \\
(0.000)\end{array}$ & $\begin{array}{l}1242.16^{* * * *} \\
(0.000)\end{array}$ & $\begin{array}{l}143.99 \\
(0.516)\end{array}$ & $\begin{array}{l}771.13^{*} \\
(0.051)\end{array}$ & $\begin{array}{c}2225.58^{* * *} \\
(0.000)\end{array}$ \\
\hline Country risk & $\begin{array}{c}6.89^{*} \\
(0.010)\end{array}$ & $\begin{array}{r}13.86 \\
(0.159) \\
\end{array}$ & $\begin{array}{r}1.83 \\
(0.692) \\
\end{array}$ & $\begin{array}{c}11.18 \\
(0.055)\end{array}$ & $\begin{array}{r}58.38 \\
(0.277) \\
\end{array}$ \\
\hline TB5y-TB3M & $\begin{array}{l}0.18^{* * * *} \\
(0.000)\end{array}$ & $\begin{array}{l}0.20^{* * *} \\
(0.000)\end{array}$ & $\begin{array}{l}0.12^{* *} \\
(0.026)\end{array}$ & $\begin{array}{c}0.16^{* *} \\
(0.021)^{* * *}\end{array}$ & $\begin{array}{c}0.13^{*} \\
(0.055) \\
* * * *\end{array}$ \\
\hline Volatility & $(0.000)$ & $\begin{array}{l}2.47^{\text {*** }} \\
(0.000)\end{array}$ & $(0.012)^{* *}$ & $\begin{array}{l}2.40^{* * * *} \\
(0.001)\end{array}$ & $\begin{array}{l}3.13^{* * * *} \\
(0.000) \\
\end{array}$ \\
\hline \multicolumn{6}{|l|}{ Firms' characteristics } \\
\hline Log total assets & & & & $\begin{array}{r}-4.23 \\
(0.264) \\
\end{array}$ & $\begin{array}{r}-4.41 \\
(0.344) \\
\end{array}$ \\
\hline Debt to total assets & & & & $\begin{array}{r}12.58 \\
(0.417) \\
\end{array}$ & $\begin{array}{r}2.84 \\
(0.860) \\
\end{array}$ \\
\hline Fixed assets to total assets & & & & $\begin{array}{r}-12.09 \\
(0.63) \\
\end{array}$ & $\begin{array}{r}-48.29 \\
(0.22) \\
\end{array}$ \\
\hline Market to book & & & & $\begin{array}{r}0.21 \\
(0.974) \\
\end{array}$ & $\begin{array}{r}3.33 \\
(0.656) \\
\end{array}$ \\
\hline Return on assets & & & & $\begin{array}{l}-57.46^{*} \\
(0.064) \\
\end{array}$ & $\begin{array}{l}-52.53^{*} \\
(0.079)\end{array}$ \\
\hline FCF to total assets & & & & $\begin{array}{l}-76.411^{* * *} \\
(0.035)\end{array}$ & $\begin{array}{l}-77.55^{*} \\
(0.068)\end{array}$ \\
\hline Industry fixed effects & Yes & No & No & Yes & No \\
\hline Number of observations & 3,239 & 2,675 & 564 & 601 & 523 \\
\hline Adjusted $\mathrm{R}^{2}$ & 0.93 & 0.94 & 0.92 & 0.93 & 0.93 \\
\hline Anderson's LR statistic ${ }^{a}$ & 12.58 & 16.29 & 2.33 & 4.46 & 3.41 \\
\hline$p$-value & $(0.000)$ & $(0.000)$ & $(0.098)$ & $(0.012)$ & $(0.034)$ \\
\hline Hansen's J-statistic ${ }^{\mathrm{b}}$ & 0.27 & 0.00 & 1.90 & 3.49 & 1.35 \\
\hline$p$-value & $(0.605)$ & $(0.969)$ & $(0.169)$ & $(0.062)$ & $(0.245)$ \\
\hline
\end{tabular}

$* p$-value $<0.10, * * p$-value $<0.05, * * * p$-value $<0.01$. 
Figure 1: The term structure of credit spreads

Graphs A, C and E plot spread against maturity, they plot the prediction from a quadratic regression and add the confidence interval on the basis of the standard error of forecast. Graphs B, D and F present the augmented componentplus-residual plot based on models [2], [3] and [4], and depict the partial relationship between spread and maturity, once all other micro and macro factors have been controlled for. The straight line corresponds to the regression model. The curved line reflects the fitting process based on the non-parametric regression called local weighted scatterplot smoothing (lowess) [see Baum (2006)].
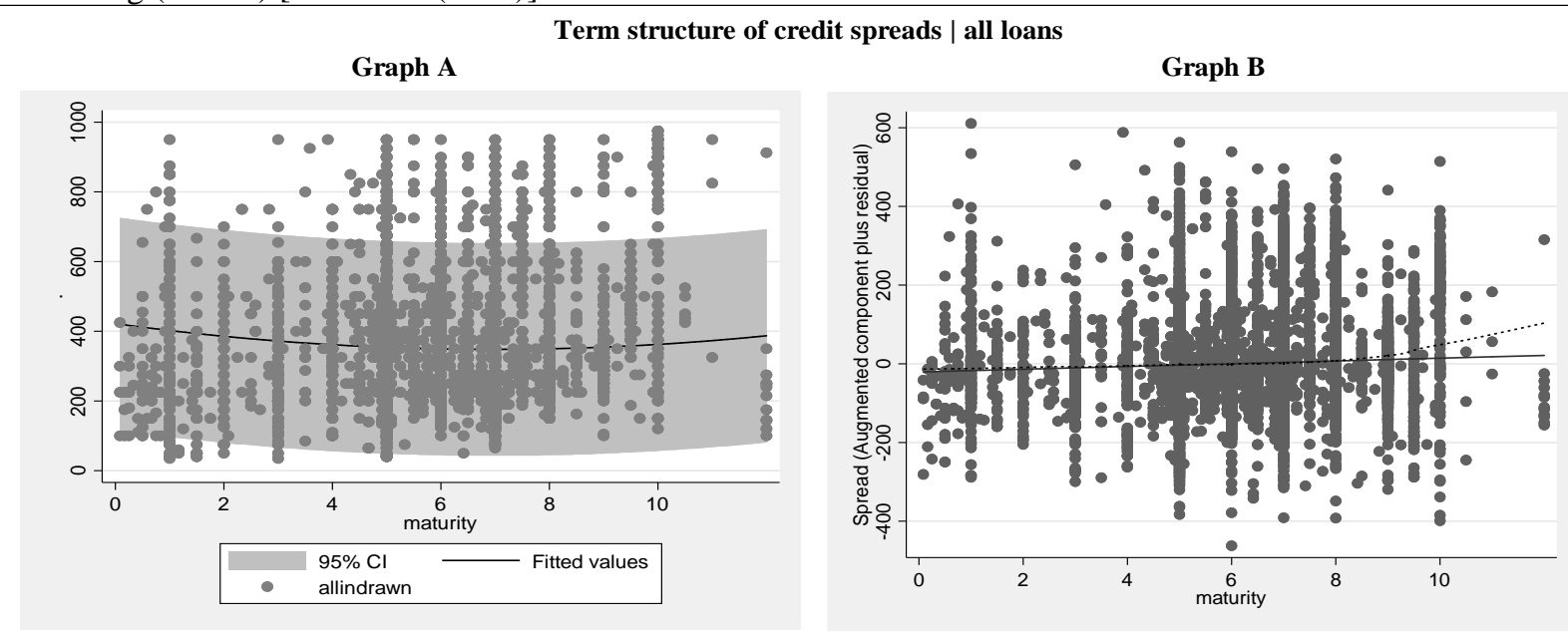

Term structure of credit spreads | market-based financial systems

Graph C

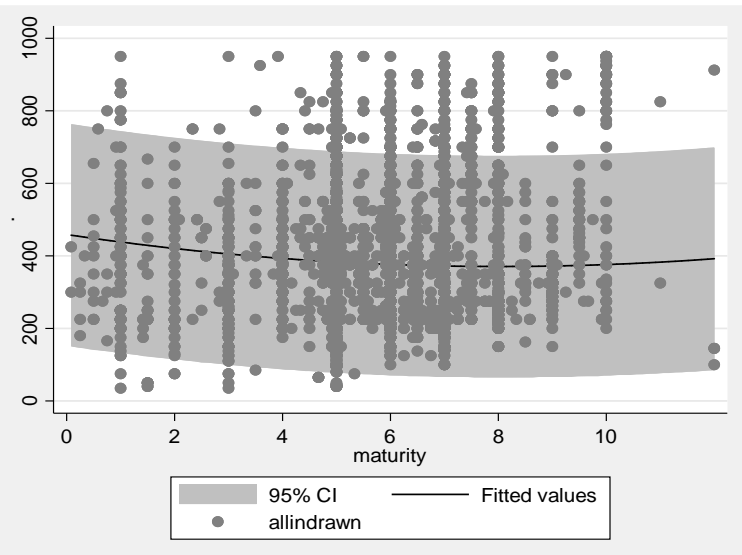

Graph D

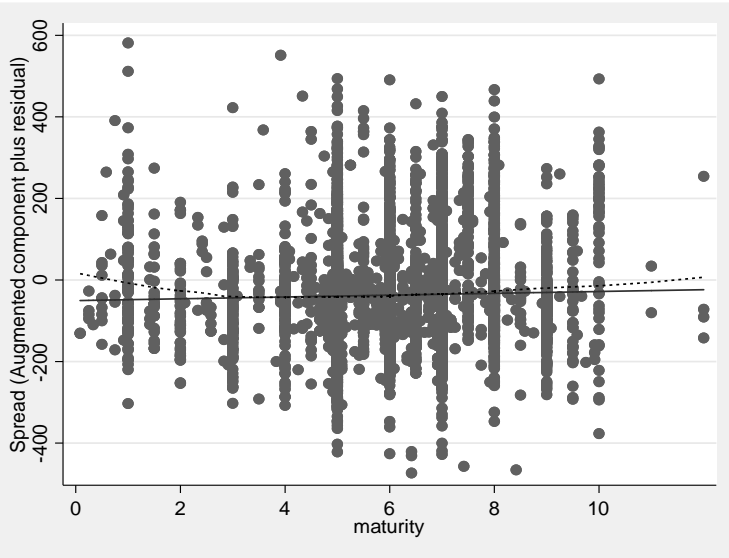

Term structure of credit spreads | bank-based financial systems

Graph E

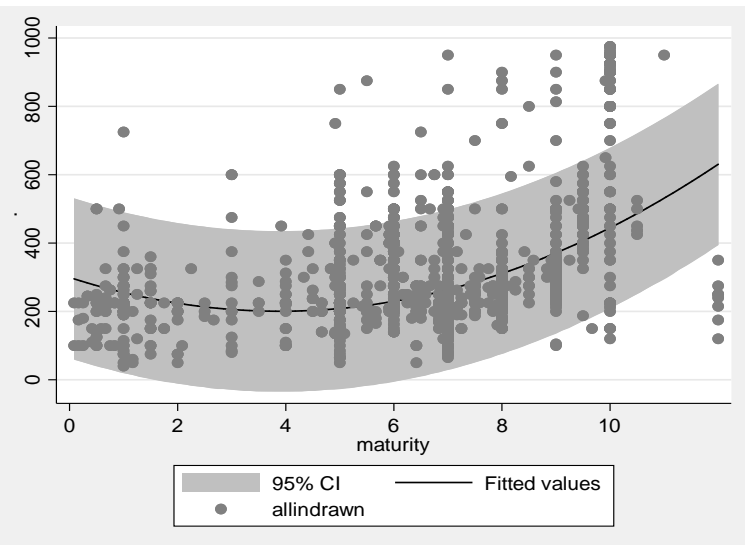

Graph F

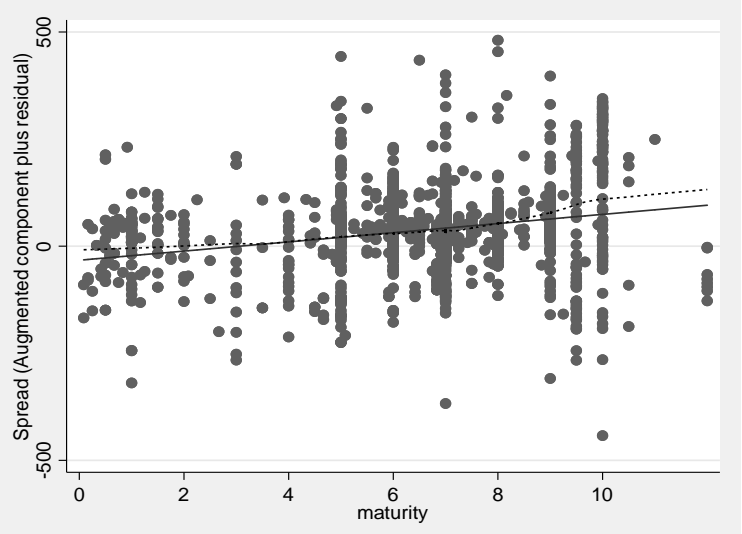




\section{Appendix}

Table A.1: Countries in the sample and their financial system and legal regime

Common law dummy takes the value 1 for common-law countries and the value 0 for others. Market-based dummy takes the value 1 for countries with market-based financial systems and 0 for countries with bank-based financial systems. Countries are classified as having a market-based versus a bank-based financial system following the approach of Demirgüç-Kunt and Levine (1999) and Demirgüc-Kunt and Maksimovic (2002). The IMF Financial System Stability Assessment report corroborates our approach.

\begin{tabular}{|c|c|c|c|c|c|}
\hline Country & $\begin{array}{c}\text { Common law } \\
\text { dummy }\end{array}$ & $\begin{array}{c}\text { Market-based } \\
\text { dummy }\end{array}$ & Country & $\begin{array}{c}\text { Common law } \\
\text { dummy }\end{array}$ & $\begin{array}{c}\text { Market-based } \\
\text { dummy }\end{array}$ \\
\hline Australia & 1 & 1 & Korea (South) & 0 & 1 \\
\hline Austria & 0 & 0 & Kosovo & 0 & 0 \\
\hline Bahamas & 1 & 0 & Luxembourg & 0 & 0 \\
\hline Barbados & 1 & 0 & Malaysia & 1 & 1 \\
\hline Belgium & 0 & 0 & Maldives & 1 & 0 \\
\hline Bermuda & 1 & 0 & Malta & 1 & 0 \\
\hline Brazil & 0 & 1 & Mauritius & 1 & 0 \\
\hline Bulgaria & 0 & 0 & Mexico & 0 & 1 \\
\hline Canada & 1 & 1 & Netherlands & 0 & 1 \\
\hline Cayman Islands & 1 & 0 & New Zealand & 1 & 0 \\
\hline Chile & 0 & 1 & Norway & 0 & 0 \\
\hline China & 0 & 0 & Pakistan & 1 & 0 \\
\hline Colombia & 0 & 0 & Peru & 0 & 1 \\
\hline Czech Republic & 0 & 0 & Philippines & 0 & 1 \\
\hline Denmark & 0 & 0 & Poland & 0 & 0 \\
\hline Dominican Republic & 1 & 0 & Portugal & 0 & 0 \\
\hline Egypt & 0 & 0 & Romania & 0 & 0 \\
\hline Finland & 0 & 0 & Russia & 0 & 0 \\
\hline France & 0 & 0 & Serbia & 0 & 0 \\
\hline Germany & 0 & 0 & Singapore & 1 & 1 \\
\hline Greece & 0 & 0 & Slovenia & 0 & 0 \\
\hline Hong Kong & 1 & 1 & South Africa & 1 & 0 \\
\hline Hungary & 0 & 0 & Spain & 0 & 0 \\
\hline Iceland & 1 & 0 & Sweden & 0 & 1 \\
\hline India & 1 & 0 & Switzerland & 0 & 0 \\
\hline Indonesia & 0 & 0 & Taiwan & 0 & 0 \\
\hline Ireland & 1 & 0 & Turkey & 0 & 1 \\
\hline Israel & 1 & 0 & United Arab Emirates & 0 & 0 \\
\hline Italy & 0 & 0 & United Kingdom & 1 & 1 \\
\hline Japan & 0 & 0 & USA & 1 & 1 \\
\hline
\end{tabular}


Table A.2: Distribution of loans by year and financial system

This table presents the distribution of the full sample of loans by year and financial system. Data are for tranches reported in DealScan with a deal specific purpose code of 'leveraged buy-out' and with tranche amount or deal amount available, during the 2000-2016 period. We have excluded deals with the status 'not closed' or 'not completed' and verified with Thomson Reuters that the primary purpose of each loan is the same for each specific deal, and that the sum of all loans equals the deal amount.

\begin{tabular}{|c|c|c|c|c|c|c|c|c|c|}
\hline \multicolumn{4}{|c|}{ All loans } & \multicolumn{3}{|c|}{ Market-based } & \multicolumn{3}{|c|}{ Bank-based } \\
\hline Year & Number of loans & $\begin{array}{l}\text { Total Value } \\
\text { (\$US million) }\end{array}$ & $\begin{array}{c}\text { Percent of Total } \\
\text { Value }\end{array}$ & Number of loans & $\begin{array}{l}\text { Total Value } \\
\text { (\$US million) }\end{array}$ & $\begin{array}{c}\text { Percent of Total } \\
\text { Value }\end{array}$ & Number of loans & $\begin{array}{l}\text { Total Value } \\
\text { (\$US million) }\end{array}$ & $\begin{array}{c}\text { Percent of Total } \\
\text { Value }\end{array}$ \\
\hline 2000 & 659 & 54,340 & $2.64 \%$ & 530 & 44,367 & $2.15 \%$ & 129 & 9,973 & $0.48 \%$ \\
\hline 2001 & 500 & 44,267 & $2.15 \%$ & 349 & 30,846 & $1.50 \%$ & 151 & 13,422 & $0.65 \%$ \\
\hline 2002 & 577 & 50,781 & $2.47 \%$ & 357 & 28,705 & $1.39 \%$ & 220 & 22,076 & $1.07 \%$ \\
\hline 2003 & 787 & 87,930 & $4.27 \%$ & 492 & 55,189 & $2.68 \%$ & 295 & 32,741 & $1.59 \%$ \\
\hline 2004 & 1,125 & 109,571 & $5.32 \%$ & 752 & 80,011 & $3.89 \%$ & 373 & 29,560 & $1.44 \%$ \\
\hline 2005 & 1,391 & 181,711 & $8.83 \%$ & 912 & 111,761 & $5.43 \%$ & 479 & 69,950 & $3.40 \%$ \\
\hline 2006 & 1,914 & 283,417 & $13.77 \%$ & 1,131 & 194,230 & $9.43 \%$ & 783 & 89,187 & $4.33 \%$ \\
\hline 2007 & 2,070 & 471,979 & $22.92 \%$ & 1,431 & 373,918 & $18.16 \%$ & 639 & 98,061 & $4.76 \%$ \\
\hline 2008 & 1,079 & 161,382 & $7.84 \%$ & 629 & 107,205 & $5.21 \%$ & 450 & 54,177 & $2.63 \%$ \\
\hline 2009 & 231 & 22,427 & $1.09 \%$ & 143 & 13,223 & $0.64 \%$ & 88 & 9,203 & $0.45 \%$ \\
\hline 2010 & 483 & 62,874 & $3.05 \%$ & 410 & 50,254 & $2.44 \%$ & 73 & 12,620 & $0.61 \%$ \\
\hline 2011 & 560 & 88,470 & $4.30 \%$ & 396 & 62,933 & $3.06 \%$ & 164 & 25,537 & $1.24 \%$ \\
\hline 2012 & 463 & 49,941 & $2.43 \%$ & 341 & 32,747 & $1.59 \%$ & 122 & 17,194 & $0.84 \%$ \\
\hline 2013 & 499 & 94,742 & $4.60 \%$ & 371 & 79,219 & $3.85 \%$ & 128 & 15,523 & $0.75 \%$ \\
\hline 2014 & 659 & 102,779 & $4.99 \%$ & 450 & 69,873 & $3.39 \%$ & 209 & 32,906 & $1.60 \%$ \\
\hline 2015 & 632 & 93,826 & $4.56 \%$ & 446 & 76,653 & $3.72 \%$ & 186 & 17,173 & $0.83 \%$ \\
\hline 2016 & 766 & 98,438 & $4.78 \%$ & 498 & 73,525 & $3.57 \%$ & 268 & 24,913 & $1.21 \%$ \\
\hline Total & 14,395 & $2,058,873$ & $100.00 \%$ & 9,638 & $1,484,658$ & $72.11 \%$ & 4,757 & 574,215 & $27.89 \%$ \\
\hline
\end{tabular}


Table A.3: Top lead banks and composition of debt in LBOs

Panel A provides information on the top lead banks and their relative importance in LBO markets by volume and number of deals, while Panel B reports the composition of debt in LBOs in market-based versus bank-based financial systems. Tranches are grouped in six categories: (i) term loans A and revolving credit facilities; (ii) second-lien term loans; (iii) bridge loans; (iv) term loans B, or higher; (v) mezzanine; and (vi) other. Data are for tranches reported in DealScan with a deal specific purpose code of 'leveraged buy-out' and with spread and tranche amount or deal amount available, closed during the 2000-2016 period.

Panel A: Top lead banks

\begin{tabular}{|c|c|c|c|c|c|}
\hline \multicolumn{3}{|l|}{ Market-based } & \multicolumn{3}{|l|}{ Bank-based } \\
\hline & $\begin{array}{c}\text { By value of } \\
\text { deals }(\%)\end{array}$ & $\begin{array}{c}\text { By number } \\
\text { of deals }(\%)\end{array}$ & & $\begin{array}{c}\text { By value of } \\
\text { deals }(\%)\end{array}$ & $\begin{array}{c}\text { By number } \\
\text { of deals }(\%)\end{array}$ \\
\hline Bank of America & $4.24 \%$ & $9.66 \%$ & Deutsche Bank AG & $3.46 \%$ & $9.00 \%$ \\
\hline Credit Suisse & $5.02 \%$ & $8.90 \%$ & Lloyds Bank & $7.27 \%$ & $8.13 \%$ \\
\hline Goldman Sachs \& Co & $4.20 \%$ & $7.96 \%$ & JP Morgan & $2.24 \%$ & $5.51 \%$ \\
\hline Lloyds Bank & $7.23 \%$ & $6.00 \%$ & Credit Suisse & $3.22 \%$ & $5.30 \%$ \\
\hline Citigroup & $1.76 \%$ & $4.50 \%$ & Le Credit Lyonnais SA & $5.17 \%$ & $5.11 \%$ \\
\hline Deutsche Bank AG & $2.22 \%$ & $3.47 \%$ & Commerzbank AG & $6.56 \%$ & $4.88 \%$ \\
\hline Barclays & $2.50 \%$ & $2.77 \%$ & Goldman Sachs \& Co & $2.18 \%$ & $4.82 \%$ \\
\hline Royal Bank of Canada & $1.38 \%$ & $2.64 \%$ & Societe Generale SA & $4.87 \%$ & $3.83 \%$ \\
\hline Wells Fargo Bank & $2.09 \%$ & $2.51 \%$ & ING Group & $3.07 \%$ & $3.39 \%$ \\
\hline Merrill Lynch \& Co & $2.01 \%$ & $2.28 \%$ & BNP Paribas SA & $6.71 \%$ & $3.18 \%$ \\
\hline \multicolumn{6}{|c|}{ Panel B: LBO debt tranches per loan type } \\
\hline \multirow[t]{2}{*}{ Market-based } & & & Bank-based & & \\
\hline & Number & $\begin{array}{l}\text { \% of total } \\
\text { LBO debt }\end{array}$ & & Number & $\begin{array}{l}\text { \% of total } \\
\text { LBO debt }\end{array}$ \\
\hline Term loans A \& revolving credit facilities & 3,749 & $23.10 \%$ & Term loans A \& revolving credit facilities & 1,267 & $30.64 \%$ \\
\hline Second-lien term loans & 1,489 & $17.88 \%$ & Second-lien term loans & 353 & $19.51 \%$ \\
\hline Bridge loans & 106 & $6.49 \%$ & Bridge loans & 74 & $3.29 \%$ \\
\hline Term loans B, or higher & 2,273 & $49.54 \%$ & Term loans B, or higher & 1,003 & $36.94 \%$ \\
\hline Mezzanine & 7 & $0.09 \%$ & Mezzanine & 19 & $0.49 \%$ \\
\hline Other & 320 & $2.90 \%$ & Other & 451 & $9.13 \%$ \\
\hline
\end{tabular}


Table A.4: Descriptive statistics

This table presents the descriptive statistics of our sample. Data are for loans/deals reported in DealScan with a deal specific purpose code of 'leveraged buy-out' and with spread and tranche amount or deal amount available, during the 2000-2016 period. Target firms' accounting and market data were obtained from Datastream. For a definition of the variables, see Table 2 .

\begin{tabular}{|c|c|c|c|c|c|c|}
\hline \multicolumn{7}{|c|}{ Panel A: Continuous variables } \\
\hline Variable of interest & Number & Mean & Median & Std. Dev. & Min. & Max. \\
\hline \multicolumn{7}{|l|}{ Contractual characteristics } \\
\hline Spread (bps) & 11,111 & 352.66 & 325.00 & 155.91 & 35.00 & 975.00 \\
\hline WAS (bps) & 9,308 & 371.70 & 361.17 & 128.15 & 35.00 & 950.00 \\
\hline Maturity (years) & 11,111 & 6.24 & 6.00 & 1.63 & 0.08 & 16.17 \\
\hline Loan size ( $\$$ million) & 11,111 & 146.35 & 50.00 & 329.66 & 0.63 & $7,000.00$ \\
\hline Deal size (\$ million) & 11,111 & 596.18 & 215.00 & $1,168.09$ & 9.06 & $12,178.90$ \\
\hline Loan size to deal size & 11,111 & $32.40 \%$ & $21.83 \%$ & $26.73 \%$ & $0.09 \%$ & $100.00 \%$ \\
\hline Tranch rank & 11,111 & 1.69 & 1.00 & 0.97 & 1.00 & 8.00 \\
\hline Number of tranches & 11,111 & 4.02 & 4.00 & 1.96 & 1.00 & 16.00 \\
\hline Upfront fee (bps) & 3,484 & 121.90 & 100.00 & 121.33 & 0.00 & 275.00 \\
\hline Commitment fee (bps) & 138 & 48.08 & 45.83 & 14.79 & 28.33 & 140.00 \\
\hline Rating [1-22 weak] & 2,033 & 14.70 & 15.00 & 2.24 & 1.00 & 22.00 \\
\hline Number of lenders & 11,111 & 5.76 & 4.00 & 5.66 & 1.00 & 58.00 \\
\hline Bank reputation & 11,111 & 12.27 & 9.00 & 9.92 & 1.00 & 26.00 \\
\hline Covenant intensity & 999 & $43.16 \%$ & $33.33 \%$ & $21.60 \%$ & $16.67 \%$ & $100.00 \%$ \\
\hline \multicolumn{7}{|l|}{ Macroeconomic factors } \\
\hline Country risk [1-22 weak] & 11,111 & 1.29 & 1.00 & 1.16 & 1.00 & 15.00 \\
\hline Creditor rights & 11,111 & 1.65 & 1.00 & 1.23 & 0.00 & 4.00 \\
\hline Enforcement & 11,111 & 46.68 & 47.61 & 2.37 & 20.42 & 49.96 \\
\hline Antidirector rights & 11,111 & 3.16 & 3.00 & 1.27 & 0.00 & 5.00 \\
\hline GDP per capita & 11,111 & 10.63 & 10.71 & 0.31 & 7.01 & 11.56 \\
\hline Volatility & 11,111 & 18.40 & 16.32 & 7.58 & 9.89 & 80.86 \\
\hline 5yTB-3mTB (bps) & 11,111 & 92.90 & 97.96 & 89.80 & -115.00 & 303.27 \\
\hline \multicolumn{7}{|l|}{ Firms' characteristics } \\
\hline Total assets (\$ million) & 788 & $11,611.58$ & 672.58 & $86,476.88$ & 105.44 & $1,459,737.00$ \\
\hline Debt to total assets & 788 & $30.41 \%$ & $25.86 \%$ & $31.57 \%$ & $0.00 \%$ & $400.10 \%$ \\
\hline Short-tem debt to total debt & 705 & $25.62 \%$ & $11.02 \%$ & $31.20 \%$ & $0.00 \%$ & $100.00 \%$ \\
\hline Fixed assets to total assets & 786 & $27.07 \%$ & $20.83 \%$ & $24.10 \%$ & $0.00 \%$ & $95.15 \%$ \\
\hline Market to book ratio & 781 & $112.40 \%$ & $92.48 \%$ & $101.84 \%$ & $0.00 \%$ & $935.31 \%$ \\
\hline Return on assets & 757 & $2.03 \%$ & $5.41 \%$ & $39.97 \%$ & $-92.77 \%$ & $75.92 \%$ \\
\hline Free cash flow to assets & 788 & $8.17 \%$ & $7.71 \%$ & $11.98 \%$ & $-90.52 \%$ & $96.31 \%$ \\
\hline Z-score & 589 & 3.21 & 2.60 & 14.87 & -16.16 & 218.47 \\
\hline \multicolumn{7}{|l|}{ Panel B: Dummy variables } \\
\hline & N. of issues with & ta available & $\%$ of total av & ilable data & Std. & \\
\hline Market-based & & 11,111 & & $71.50 \%$ & & $45.15 \%$ \\
\hline Tranched & & 11,111 & & $96.58 \%$ & & $16.42 \%$ \\
\hline Rated & & 11,111 & & $18.30 \%$ & & $38.67 \%$ \\
\hline Fee information & & 11,111 & & $32.31 \%$ & & $46.77 \%$ \\
\hline Secured & & 9,367 & & $98.37 \%$ & & $12.68 \%$ \\
\hline Term loan & & 11,111 & & $64.66 \%$ & & $47.81 \%$ \\
\hline Currency risk & & 11,111 & & $8.58 \%$ & & $28.00 \%$ \\
\hline Subordinated & & 11,111 & & $2.57 \%$ & & $15.84 \%$ \\
\hline Former lender & & 11,111 & & $9.01 \%$ & & $28.63 \%$ \\
\hline Domestic lead bank & & 11,111 & & $68.97 \%$ & & $46.26 \%$ \\
\hline Crisis & & 11,111 & & $27.57 \%$ & & $44.69 \%$ \\
\hline Fixed rate loan & & 11,111 & & $2.87 \%$ & & $16.70 \%$ \\
\hline
\end{tabular}


Table A.5: Descriptive statistics for target firms by type of financial system

We test for similar distributions in public firms' characteristics across samples via the Wilcoxon rank-sum test. For a definition of the variables, see Table $2 . * * * * *$, and * indicate significant difference at the $1 \%, 5 \%$, and $10 \%$ levels, respectively, between sub-samples.

\begin{tabular}{|c|c|c|c|c|}
\hline \multicolumn{2}{|l|}{ Variable of interest } & \multirow{2}{*}{$\begin{array}{l}\text { All firms } \\
11,611.58\end{array}$} & \multirow{2}{*}{$\begin{array}{r}\text { Market-Based } \\
11,606.00\end{array}$} & \multirow{2}{*}{$\begin{array}{r}\text { Bank-Based } \\
11,639.08\end{array}$} \\
\hline Total assets (\$ million) & Mean & & & \\
\hline & Median & 672.58 & 660.15 & 711.94 \\
\hline & Number & 788 & 655 & 133 \\
\hline \multirow[t]{3}{*}{ Debt to total assets } & Mean & $30.41 \%$ & $30.99 \%$ & $27.52 \%{ }^{* *}$ \\
\hline & Median & $25.86 \%$ & $26.50 \%$ & $23.65 \%$ \\
\hline & Number & 788 & 655 & 133 \\
\hline \multirow[t]{3}{*}{ Short-tem debt to total debt } & Mean & $25.62 \%$ & $24.03 \%$ & $33.29 \%$ *** \\
\hline & Median & $11.02 \%$ & $8.56 \%$ & $26.81 \%$ \\
\hline & Number & 705 & 584 & 121 \\
\hline \multirow[t]{3}{*}{ Fixed assets to total assets } & Mean & $27.07 \%$ & $27.63 \%$ & $24.31 \%$ \\
\hline & Median & $20.83 \%$ & $21.26 \%$ & $20.01 \%$ \\
\hline & Number & 786 & 653 & 133 \\
\hline \multirow[t]{3}{*}{ Market to book ratio } & Mean & $112.40 \%$ & $112.42 \%$ & $112.32 \%$ \\
\hline & Median & $92.48 \%$ & $93.32 \%$ & $89.94 \%$ \\
\hline & Number & 781 & 650 & 131 \\
\hline \multirow[t]{3}{*}{ FCF to total assets } & Mean & $8.17 \%$ & $8.43 \%$ & $6.86 \%$ \\
\hline & Median & $7.71 \%$ & $7.78 \%$ & $7.37 \%$ \\
\hline & Number & 788 & 655 & 133 \\
\hline \multirow[t]{3}{*}{ Return on assets } & Mean & $2.03 \%$ & $0.88 \%$ & $3.64 \%{ }^{*}$ \\
\hline & Median & $5.41 \%$ & $5.43 \%$ & $4.78 \%$ \\
\hline & Number & 757 & 630 & 127 \\
\hline \multirow[t]{3}{*}{ Z-score } & Mean & 3.21 & 3.26 & 2.96 \\
\hline & Median & 2.60 & 2.62 & 2.53 \\
\hline & Number & 589 & 493 & 96 \\
\hline
\end{tabular}

